\title{
Auditors' ethical reasoning in developing countries: The case of Egypt
}

\author{
Engy E. Abdelhak
}

Department of Accounting, Port Said Technological College, Port Said, Egypt

\begin{abstract}
Ahmed A. Elamer *
Brunel Business School, Brunel University London, Kingston Lane, Uxbridge, London, UB8 3PH UK; and

Department of Accounting, Faculty of Commerce, Mansoura University, Mansoura, Egypt Email: ahmed.a.elamer@gmail.com

*Corresponding author

\section{Craig McLaughlin}

Strathclyde Business School, University of Strathclyde, Glasgow, G1 1XQ, Scotland Email: craig.mclaughlin.100@strath.ac.uk

\footnotetext{
Aws AlHares

Department of Accountancy and Finance, Business School, University of Huddersfield, UK, and

Faculty of School of Business Studies, College of the North Atlantic in Qatar, Qatar Email: aalhares@yahoo.co.uk
}

Full reference: Abdelhak, E., Elamer, A., \& AlHares, A. (2019) 'Auditors' ethical reasoning in developing countries: The case of Egypt, International Journal of Ethics and Systems. Forthcoming (Accepted $7^{\text {th }}$ June 2019). 


\title{
Auditors' ethical reasoning in developing countries: The case of Egypt
}

\begin{abstract}
Purpose - The aim of this research is to investigate Egyptian auditors ethical reasoning, to understand whether auditors' ethical reasoning is influenced by audit firm size or/and auditor position.

Design/methodology/approach - This paper draws on 178 questionnaires that include six different ethical scenarios. This paper also uses AEDI (Accounting Ethical Dilemma Instrument) that is developed by Thorne (2000) to measure the ethical reasoning of Egyptian auditors.

Findings - The findings are three-fold. First, this study finds that the general level of deliberative ethical reasoning of auditors working in CAO (The Central Auditing Organization) and small firms are categorized in the post-conventional level, while auditors working in Big and Medium firms categorized in conventional level. Second, the result suggests that there is a negative relationship between ethical reasoning and audit firm size in Egypt. Finally, the results show that ethical reasoning levels decrease when the position of auditors increase except for auditors working in CAO.

Originality/value - This study adds to the scarce literature in developing countries that measure auditors' ethical reasoning. The findings suggest that auditors' ethical reasoning depend on auditor firm size and the position the auditor holds within the firm. These findings will aid policy makers and regulators, especially in developing countries to avoid any potential risks regarding professional misconduct and in evaluating the adequacy of the current code of ethics.
\end{abstract}

Keywords Ethical reasoning; AEDI, Defining Issues Test, Egypt

Paper type Research paper 


\section{Introduction}

This study examines the nature of auditors' ethical reasoning in Egypt. It adds to the limited research on the ethics of practicing auditing in a unique context. Egypt is a developing country with a different cultural and economic environment, in which ethical reasoning of auditors has not been measured before to the best of our knowledge. This study, also explores the relationship between different levels of ethical reasoning and both audit firm size and position level of auditor.

Aristotle in his remarkable book the Nicomachean ethics points out the difference between art and ethics by contrasting voluntary error with involuntary error. In art, no matter what you are doing, you can portray your thinking in a clear or unclear manner; in ethics, we judge the ultimate purpose of the art. The etymology of the word 'ethics' has origins with the Greek word 'ethikos' which means 'usage' and was much used by Aristotle to signify valuable fundamental convictions, while the word 'moralis', the Latin root for 'moral', was established by Cicero to mean, values growing from a complex body of beliefs (Ardelean, 2013). Aristotle's introduction may support the ideas of Chow et al. (2014), being that the auditor needs to apply professional values and act for the public's interest, as such are the cornerstones of many auditing concepts. These values include due care, independence, objectivity, professional skepticism, and integrity rather than commercialism that focus on self-interest.

Moral reasoning is a well-established psychological construct that refers to the set of cognitive skills an individual uses to resolve moral dilemmas with four sequential components of the ethical reasoning process: sensitivity in identifying the existence of a moral question, ethical evaluation of that situation, intention to act morally in regard to that issue, and actual moral behavior on it (Arnold et al., 2013; Iqbal \& Sholihin, 2019; Moardi et al., 2016; Sayyadi Tooranloo \& Azizi, 2018; Wilhelm and Gunawong, 2016). For example, an auditor who issues an audit opinion may face pressures and ethical dilemmas (Espinosa -Pike and Barrainkua, 2016). Auditors often have two choices: the first choice is to issue an opinion on the financial statements that is more beneficial for the client and the auditor/client relationship. Thus, achieving a personal benefit for the auditor by continuing his business and consolidating the relationship with the other party. The second option is to issue an opinion on the financial statements in accordance with standards and codes of ethics, which could lead to client loss in the 
future. Both of these arguments are closely related to Agency theory in Auditing as discussed by Jensen and Meckling (1976).

In essence, the nature of each auditor may differ in analyzing the pressures perceived in their professional activity to solve the ethical dilemmas (Espinosa-Pike and Barrainkua, 2016). Some auditors believe that personal interest and stability of relationship with the client and balance of profit and loss is the best choice. Some of them believe that compliance with Auditing Standards and professional bodies' code of best practice and ethics is the only option, regardless of their personal opinion.

As a result, there is an increasing need for the professional ethics in all professions in general (Arnold et al., 2013; Doyle et al., 2013), especially in occupations that rely on the professional judgement, such as auditing. High standards of professional ethics are central to the accounting profession and any compromise of ethical codes could undermine the financial reporting quality (Albeksh, 2016). This is particularly important since the society expects the auditors to have a superior (Ethical Reasoning) that qualifies them to face the pressures of clients and to produce independent professional judgments (Haron et al., 2015). According to International Ethics Standards Board for Accountants, IESBA, (2016), practitioners must comply with and provide a conceptual framework for applying specific principles (i.e., integrity, objectivity, professional competence and due care, confidentiality and conduct professional behavior). Furthermore, the auditor must maintain both real independence and perceived independence, however what is fundamentally important is the level of professional skepticism being employed.

The Egyptian Auditing Standards are adopted from International Auditing Standards (IASs) after being translated into Arabic, with the auditor independence requirements being closely matched to the international requirements. Auditors must remain independent by fact and by nature at all times and must avoid any conflict of interest through fully disclosing all the threats to independence and making informed decisions about audit acceptance or continuance. In addition, auditors are banned from accepting any material value gifts presented to them or to their family to ensure independence on all levels is maintained. Having any direct financial interest or material indirect (for one of auditor's family members or colleagues at the same firm) financial interest at the client, being employed or having close relationships with employees are all signals of potential ethical and independence issues and an adequate 
cooling off period becomes fundamental before working as an ex-auditee. Hence, the reasons for lack of independence appear to be not a matter of regulations in the Egyptian context but rather a personal, culture or a cognitive issue (Mostafa et al., 2017).

Corporate scandals like Enron, WorldCom, Adelphia and Tyco had reignited the debate regarding the concept of auditor ethical reasoning worldwide (Adhikariparajul et al., 2019; Alnabsha et al., 2018; Elamer et al., 2018, 2019; Elamer \& Benyazid, 2018; Elamer et al., 2017). In addition, these scandals accelerated the introduction and continued development of the Sarbanes Oxley Act (SOX), in USA in 2002, which aims to overcome unethical business practices. The SOX also aims to strengthen corporate governance and regain investors' confidence in the US financial system. However, more recent corporate scandals after the enactment of the SOX such as the Lehman Brothers, which collapsed in 2008. This dramatically affected the 2008 crisis (Adhikariparajul et al., 2019; Alshbili et al., 2019; Elmagrhi et al., 2019; Gerged et al., 2018; Spector et al., 2014) and indicates that more can be done to ensure ethical reasoning is at the forefront of every decision.

The revelation of accounting irregularities that taken place in Middle East and North Africa (MENA) also caused regulators, researchers and the media to focus extensive attention on ethical reasoning, especially in the audit firms. For example, in 2014, an accounting scandal was occurred in Saudi Arabia. MMG (Mohammad Al Mojil Group) share price was dropped from 20 dollars to 30 cent in a short time period (Zerban, 2017; Zureigat, 2014), which was audited by Deloitte. Consequently, in June 2015, Deloitte's unit in Saudi Arabia has been banned from doing auditing work in the country for the next two years (Peterson, 2017; Zerban, 2017). The ban follows a letter sent by the Capital Markets Authority (CMA) to companies and entities that its licenses advising them not to use Deloitte's audit services from June 2015. CMA investigated the share price reaction of MMG and a fine of 300,000 Saudi Riyal $(£ 54,572)$ was also imposed to the audit firm. PricewaterhouseCoopers (PWC) also was auditing the Saudilisted telephone provider Mobily, which reportedly another investigation target after profit cuts. Specifically, Mobily stock price collapse from nearly 20 dollars in 2012 to nearly 5.3 dollars on 12 January 2017, which consider as an administrative and accounting scandal (Peterson, 2017). This mainly because Mobily made a mistake in calculating the revenues of the customer loyalty program and discovered this error at the beginning of 2014, but unfortunately it was not announced until 9 months later. 
Mobily says it discovered the error and told the external auditor -PWC- that it would correct the error from revenue in 2014 and the external auditor initially accepted it but returned to inform the company in late October 2014 that this method was improper and requested a deduction from 2013 revenues.

Egyptian financial regulatory authority (EFSA) recently on 20 June 2016 issued two statements related to auditing irregularities and scandals. First, EFSA found that three auditors unsatisfactory performed their duties with the required quality and training level, thus EFSA issued a warning regarding an existing violation and the necessity of taking action to remedy the same and ensure prevention of repetition. Second and more importantly, EFSA delisting an auditor "Abdullah Anany" on 20th June 2016 due to significant breaches regarding quality standards and incompliance with auditing standards (EFSA, 2016). Consequently, three listed companies were obliged to change their audit firm (i.e., Anany \& Co). Also, in Egypt, many questions raised by the participation of large audit firms in the assessment of the government assets, which was less than its real value during privatisation process (Dahi, 2012; Puddephatt, 2012). All the above scandals led to significant market reactions. These incidents negatively affect investor trust in the audit profession and made the ethical reasoning of the auditors is questionable. This provide an apparently influential setting to explore the reasons that affect auditors' ethical reasoning in Egypt.

Therefore, this study aims to distinctively make a number of new contributions to the extant literature. First, we contribute to extant research by measuring auditors' ethical reasoning in Egypt, which remains largely unexplored. Specifically, most of the empirical research explored ethical reasoning focused on developed countries (e.g., Jones et al,2003; Flemming et al,2009; Flemming et al,2010). The evidence related to the effects of audit firm size and auditor position on ethical reasoning level in developing countries, is still lacking. Second, our unique sample contains auditors from small, medium and large auditing firms ${ }^{1}$. In addition, we add auditors from CAO, which is a governmental auditing organization. This is contrary to the majority of studies that based on testing accounting students or accountants after ethical educational courses (e.g., Christensen, 2016; Sorensen et al., 2017).

\footnotetext{
${ }^{1}$ Many researchers divide big, medium and small enterprises based on the number of workers working on each of theme ( Yunjarti,2011 ; Berisha\&shiroka,2015), so we divide medium auditing office that contains more than twenty auditors and small auditing offices that contain from 1 auditor to less than 20 auditors .
} 
The remainder of this paper proceeds as follows. The next section provides background about the auditing profession in Egypt. Then, the next section reviews the relevant literature, which is followed by the development of research hypotheses. Following this, the methods and results are presented. We end with a discussion of our findings and concluding comments.

\section{Auditing profession in Egypt}

Egypt has an extensive history in the field of accounting, auditing and accountability. Specifically, in the 1960s, Egypt moved to central planning economic, nationalization, and fast expansion of the public sector (Elbayoumi et al., 2019; Khlif and Samaha, 2014). The Central Auditing Organization (CAO) became the governmental auditing agency responsible for auditing the public sector, covering governmental-owned companies (CAO, 1988; Khlif and Samaha, 2014). Then, the Egyptian government announced an 'open-door' plan to liberalize the state economy. During the 1990s, the government introduced a wide-ranging economic reform and structural adjustment program reinforced by the International Monetary Fund and World Bank (Abd-Elsalam \& Weetman, 2003; Khlif and Samaha, 2014; Samaha et al., 2012). Correspondingly, Egypt was compelled to adopt International Accounting Standards as part of Egypt reform programs to regain investors' confidence (Khlif and Samaha, 2014; Samaha \& Stapleton, 2008, 2009). As a result of the above reforms and privatization, the private sector started to form a significant part of the Egyptian economy. At that time, individual auditors and private auditing offices (KPMG 2010) adopted the Generally Accepted Accounting Principles (GAAP) and the Generally Accepted Auditing Standards (GAAS) in to the private sector that was audited. Although the consistent growth of Egypt as an emerging market with great foreign investment potential (Samaha and Hegazy, 2010), governmental-owned companies is a significant part to Egyptian economy. Specifically, El-Dyasty (2017) shows that Big 4 firms and $\mathrm{CAO}$ are the main audit firms in Egypt. Big 4 control $34.40 \%$ of listed companies in Egyptian stock of exchange. Also, the CAO audits a further $22 \%$ of listed companies implying a significant dominance in the Egyptian audit market.

In recent times, Egypt has undertaken many regulatory reforms. For example, the Egyptian Accounting Standards (EAS) was introduced in 2006, the corporate governance code in 2005 and the Egyptian Standards on Auditing (ESA) which were 
introduced in early 2009 (Khlif and Samaha, 2014; Samaha and Hegazy, 2010). More interestingly, a recent update to the ESA was issued in 2015. The new ESA are mostly consistent with the International Auditing Standards (IAS). ESA and EAS are developed and revised by a professional body, discussed and adopted by a ministerial committee, and issued by ministerial decrees applicable to the Egyptian environment (Elbayoumi et al., 2019; ROSC 2002). The auditing profession in Egypt is still governed by the law 133 of 1951. However, this law and ESA does not include a professional code of conduct and penalties (ROSC, 2002). ROSC (2002) argued that auditor independence and ethics are questionable in Egypt since unqualified opinions are issued even with key material misstatements (Mokhtar and Mellett, 2013; ROSC, 2002; Samaha and Hegazy, 2010).

Given that the ESA are adopted from International Auditing Standards after being translated into Arabic, and that the auditor independence requirements are almost the same as the international requirements, if auditor encounters any potential conflict of interest, it should be fully disclosed. This disclosure must include all the conditions that lead to the conflict and give the auditor the opportunity to withdraw from or reject the engagement at the first place. Hence, the reasons of lack of independence appear to be not a matter of regulations in the Egyptian context but rather a personal, culture or a cognitive issue (Mostafa et al., 2017). Consequently, Egypt introduced a voluntary code of professional ethics for accountants and auditors in 2009. However, some auditors continue to ignore the code of ethics for practical performance because there is no official body enforcing the code compliance. Furthermore, Hegazy and Kamer (2010) argue that there is a lack of awareness among accountants and auditors about what is international best practice when addressing the issue of conflicts of interest.

\section{Literature review}

\section{Kohlberg's Theory of Cognitive Moral Development}

Kohlberg's (1969) stage theory is considered the most influential theory concerning moral development within the last past 50 years. It states that cognitive ethical reasoning becomes more complex as individuals mature and acquire additional cognitive structures. Kish-Gephart et al. (2010) describe cognitive moral development (CMD) theory by explaining the progression of individuals' ability to understand rightness or wrongness over time. The model of Kohlberg depicts six stages of ethical 
development, which are then divided into three categories that are more general. Preconventional, conventional, and post-conventional levels of moral reasoning as presented in Table 1.

\section{INSERT TABLE 1 ABOUT HERE}

According to this theory, moral development occurs in six stages in a step-by-step upward progression from lower stages of self-interest, to middle stages of law abidance and then to higher stages of adherence to universal principles of justice and human rights. These stages are categorized in three levels explained as follows.

I. Pre-conventional Level

At this level, we are responsive to cultural rules and what is right or wrong (good or bad), but we interpret the labels in terms of either the physical or hedonistic consequences of action (punishment, reward, exchange of favors) or the physical power of those who enunciate the rules and labels. Thus, auditors place more emphasis on themselves and make judgments based on the possibility of punishment or rewards. This level is divided into two stages. Stage 1: The punishment and obedience orientation, which means the physical consequences of action is determined by the positive or negative outcome, regardless of the human meaning or value of these consequences. Stage 2: Individualism and rewards (hedonistic), refers to which action satisfies the individuals own needs and occasionally the needs of others.

\section{Conventional Level}

At this level, the individual perceives the maintenance of the expectations of his family, group, or nation as valuable in its own right, regardless of immediate and obvious consequences. The attitude is not only one of conformity to personal expectations and social order, but of loyalty to it, of actively maintaining, supporting, and justifying the order and identifying with the people or group involved in it. The conventional level consists of two stages. Stage3: The interpersonal concordance or "good boy-nice girl" orientation, which means good behavior, is what pleases or helps others and is approved by them. There is much conformity to stereotypical images of what is majority or "natural" behavior. Stage 4: the "law and order" orientation. This implies that the individual respects authority, the rules, and the maintenance of the 
social order. Behavior consists of doing one's duty, showing respect for authority, and maintaining the given social order for its own sake.

III. Post-Conventional, Autonomous, or Principled Level.

The individual makes a clear effort to define moral values and principles that have validity and application apart from the authority of the group of people holding them and apart from the individual's own identification with the group. The PostConventional level has two stages. Stage 5: The social-contract legalistic orientation (generally with utilitarian overtones). The correct action tends to be referred to in terms of what society believes to be right or wrong. There is a clear awareness of the relativism of personal values and opinions and a corresponding emphasis upon procedural rules for reaching consensus. Stage 6: The universal ethical-principle orientation. Right is defined by the decision of conscience in accord with self-chosen ethical principles that appeal to logical comprehensiveness, universality, and consistency.

A number of empirical studies have examined the ethical reasoning levels of professional accountants or/and auditors using Kohlberg's CMD theory. For example, Ponemon (1990) found an association exists between the auditors' hierarchical position in their firm and their capacity for ethical reasoning. Specifically, this capacity increases in the staff and supervisory levels and then decreases in the manager and partner ranks that which means that there is a negative relationship between accountants' position in the firm and their levels of ethical reasoning. Ponemon and Gabhart (1990) conclude that there is a systematic relationship between auditors' measured ethical cognition and their resolution of an independence conflict exists. ALaidaros et al. (2014) found that Yemeni professional accountants exhibit higher level of ethical reasoning beyond the conventional level. Fleming et al. (2010) compared level of ethical reasoning between Chinese accounting students and experienced auditors with a USA sample. They found that there is cross-national differences in auditors' ethical reasoning depending on the nature of the ethical dilemma. Jones et al. (2003) limited their review to studies of auditors' ethical reasoning, covering the period from 1987 to 2003. They provide a thorough, broad review not limited to the DIT or the cognitive-developmental perspective (Bailey et al., 2010). 


\section{Rest's model and Defining Issues Test (DIT)}

Kohlberg developed a system to represent logical ethical reasoning, which was extended by Rest (1986). This model is considered a valid, reliable instrument to measure ethical reasoning. Particularly, Rest (1986) develops the DIT measure to measure of ethical reasoning objectively, which is based on the six stages of cognitive moral development scale created by Kohlberg (1969). According to Rest's model, the four-components of moral action are as follows. First stage, moral sensitivity (recognizing the ethical dilemma) is where individuals recognize the moral dimensions of an issue within a specific context. The next stage requires individuals to employ moral reasoning (judgment), which the DIT strives to measure. The third stage is moral motivation (intention), where individuals organize their priorities for taking ethical actions when facing competing demands. The fourth stage is moral character (behavior), which requires individuals to determine whether to act consistently with their motivation when they are facing a particular situation (Christensen et al., 2016).

Although the widespread use of DIT (Christensen et al., 2016; Fleming et al., 2010), a number of researchers in the field of accounting criticized the DIT ability to accurately capture the cognitive capacity for moral thinking without no biases and that there are more productive means for understanding the ethical decision process (Flory et al,1993; Sweeny and Fisher,1998; Bay, 2002). more troubling is the tentative connection between DIT score and behavior, and the possibility that the relationship may be quadratic rather than linear, and that This test measures moral development in general and does not measure the other aspects of operational processes of ethical decision-making. Thus, the ethical level of accountants is not tested in the accounting environment (Bay, 2002; Thorne 2000). Furthermore, the DIT describes the ability to make ethical judgments instead of the moral decision itself. Bailey et al. (2010) find that there is ambiguity regarding what the DIT essentially measures and, suggest it fails to reflect that moral judgment is a part of the bigger picture of ethical behavior. Also, one of the several challenges to the DIT's validity too is its correlation with political ideology (Bailey et al., 2005). For instance, Emler et al. (1983, 1999) show that politically conservative participants score higher on the DIT when asked to be like a liberal. They conclude that, although conservative people understand the reasoning associated with Kohlberg's higher stages of moral development, their DIT responses understate their true ability because of a desire to present themselves as conservative. 
DIT also measures cognitive moral capacity, and it does not necessarily correspond to the moral reasoning that accountants apply to the resolution of ethical dilemmas in the work place. Cognitive moral capacity describes the most sophisticated moral reasoning of which an individual is capable. Specifically, while traditional DIT examines individuals' moral capacity as applied to hypothetical dilemmas, the accounting specific instruments examine the prescriptive and deliberative reasoning accountants apply to the resolution of realistic ethical dilemmas. Accordingly, realistic case scenarios are used in the accounting-specific instrument to elicit representative reasoning processes (Thorne, 2000)

As a result of criticism of the DIT model (Christensen et al., 2016), we use the Accounting ethical dilemma instrument (AEDI), which is a tool developed by Thorne (2000) that used the same structure of DIT but changed the ethical dilemmas to suit the professional accounting environment. It is used to measure both deliberative reasoning (intention) and prescriptive reasoning (judgment). In practice, this tool has tried to deal with the main criticism of DIT. It used ethical accounting and auditing dilemmas that reflect the professional environment of the accounting and auditing function rather than social dilemmas while maintaining a benchmarking structure of DIT.

\section{Accounting ethical dilemma instrument (AEDI)}

Several facets of auditors' moral reasoning are relevant to their moral decision making. Context-specific measures of moral reasoning may take several forms, including prescriptive reasoning and deliberative reasoning. Accordingly, to assess accountants' prescriptive and deliberative moral reasoning in the workplace, this research relies on an audit-specific instrument that has been developed and tested by Thorne (2000). There are two versions of the audit-specific instrument: prescriptive and deliberative. Each version of the instrument is identical to the other except that each elicits one mode of the accountants' moral reasoning. The prescriptive version of the audit-specific instrument uses differencing subjects to consider how auditors should ideally resolve the described dilemmas. The deliberative version of the audit-specific instrument employs subjects to consider how auditors would realistically resolve the described dilemmas (Thorne et al., 2003).

Many authors also have used the AEDI to study ethical reasoning. For example, (Thorne et al., 2003) investigated audit-specific ethical reasoning of Canadian and U.S. 
auditors. They provide evidence that the U.S. CPAs have significantly higher deliberative ethical reasoning than their Canadian counterparts do. Fleming et al. (2009) compared U.S. accounting students' deliberative ethical reasoning scores on the AEDI to a version of the instrument adapted for management accounting environment. They found deliberative ethical reasoning to be higher in the audit context. Also, Ge and Thomas (2008) found that Canadian accounting students exhibited higher audit-specific deliberative ethical reasoning than Chinese accounting students. Fleming et al. (2010) used audit-specific ethical reasoning to assess the level of ethical reasoning between Chinese accounting students and experienced auditors, and found that there is crossnational differences in auditors' ethical reasoning depending on the nature of the ethical dilemma.

Moreover, many studies tend to investigate cross-national differences among a number of countries with many of these studies being based on the model of Hofstede (1984). Hofstede presented a model of five dimensions of national cultures: Power Distance, Uncertainty Avoidance, Individualism, Masculinity and Long Term Orientation. that was extended to explore accounting values and systems and their links to societal values and institutional norms Gray (1988). For example, the difference in societies and countries affects the auditor's ability to activate his unethical intentions (Sweeney et al., 2010) so The American auditor was less able to enforce the unethical intentions compare to the Irish auditor. Tsui and Windsor (2001) find the Australian auditors' ethical reasoning was higher than Chinese auditors were. Also, sample of a majority of business students from Australia, Singapore and Hong Kong also differ in ethical attitudes (Phau and Kea, 2007), and there are statistically significant differences between the terminal and instrumental values of the auditors in both Pakistan and Turkey (Karacaer et al., 2009).

Furthermore, previous research that use AEDI have found the instrument to have adequate validity. For example, Fleming et al. (2009) found a Cronbach's alpha of 0.55 for the four-case version of the AEDI, which is almost identical to the 0.53 alpha value that Thorne (2000) reported for this instrument. 


\section{Research Questions and Hypothesis Development}

\subsection{Level of ethical reasoning}

Ethical reasoning of professional accountants and auditors is vital to the prominence and credibility of the auditing profession. In recent years, the companies and accounting scandals such as Enron, Lehman Brothers, HBOS, Tesco and BT have raised crucial questions about the role of auditors. Allegations of auditors' violations of public trust have led to government intercession. Nevertheless, ethical issues are inherent in the working environment of auditors (Finn et al., 1988; Leung and Cooper, 1995; Ponemon and Gabhart, 1993). In performing their role, auditors have to act together with a wide range of stakeholders. Such interactions, in many cases, may result in possible conflicts of interest (Tsui, 1996). As a result, previous studies mainly focused on the examination of the levels of ethical reasoning through its stages when assessing professional ethics in accounting and auditing (Jones et al., 2003).

Ample of studies suggest a lower level of ethical reasoning in accounting and auditing students and professionals than would be expected (Armstrong 1987; Bernardi and Arnold 1997; Ponemon 1990, 1992; Shaub 1994). Other empirical results claim that auditors do not improve their levels of ethical reasoning and selection-socialization effect exists in the accounting profession that results in hiring auditors with lower levels of ethical reasoning in the profession (Ponemon 1990, 1992; Abdolmohammadi et al.,2003). The majority of literature on ethical reasoning has been undertaken in the USA, Hong Kong, and Canada. Previous evidence advocates that accountants and auditors in different nations may have diverse ethical awareness and standards, and there is a link between the ethical judgment of accounting and auditing professionals and the context with such playing an important role in the decision making process (Ba1"ada-Hire`che and Garmilis., 2016; Thorne et al., 2003 ; Fleming et al, 2010).

To date, the above research on ethical reasoning focused on auditors within the North American, Hong Kong, China, and Australia. Unfortunately, these studies have neglected to consider auditors' ethical behaviour in developing countries, such as Egypt. The above discussion leads to the following research hypothesis:

$H_{1}$ : The general ethical reasoning level of external auditors in Egypt according to AEDI test does not fall in the post-conventional level. 


\subsection{Auditing Firm size}

The size of the firm that the auditor works for is a crucial characteristic that can have an influence on auditors' ethical decision-making (Pierce and Sweeney 2010). There are many differences in characteristics between large and small auditing firms (Comprix and huang, 2015). Prior research has examined the relation between audit firm size and topics relating to ethics or professionalism, however the findings seem to be mixed. For instance, according to previous studies (Espinosa-Pike and Barrainkua, 2016; Harron et al., 2014; Naslmosavi et al., 2013) less experienced auditors and those working in medium sized audit firms are the ones who perceive the pressures to a greater extent, so threats for dysfunctional behavior arise particularly in medium sized audit firms, also practitioners in small audit firms typically do not have formal in-house training on which to rely. Hence, they often solve ethical dilemmas on their own. So factors like experience, education, skills and employee competence may have influence on quality of auditors and their opinion.

Consideration of the existing literature of auditing and accounting ethics, however, does not imply that Big 4 auditors have better ethical reasoning. Khurana and Raman (2004), and Sun and Liu (2011) suggest that litigation exposure and brand name reputation protection drive perceived audit quality in the Big 4 audit firms. Litigation is likely to be more costly for these firms in terms of the potential impairment to their brand name reputation capital (Palmrose 1988). On the other hand, according to Kohlberg theory, the pre-conventional level consists of the first two stages of the moral development; the first stage is based on punishment and obedience orientation, where what is a right thing to an individual is the action that would not lead him to be punished for harming society (weber.,2017; Arfaoui et al., 2017 Windsor and Ashkanasy, 1995).

Ford and Richardson (1994) concluded after summarizing some of the empirical studies that size of organization tends to influence ethical decision making and that as size of the organization increases, individual ethical beliefs and ethical decision-making behavior decreases. Furthermore, the revelation of accounting irregularities that taken place in Middle East and North Africa (MENA) were linked to Big 4 audit firms. For example, in 2014, an accounting scandal was occurred in Saudi Arabia. MMG (Mohammad Al Mojil Group) (Zerban, 2018; Zureigat, 2014), which was audited by Deloitte. PricewaterhouseCoopers (PWC) also was auditing the Saudi-listed telephone provider Mobily, which reportedly another investigation target after profit cuts. 
Specifically, Mobily stock price collapse from nearly 20 dollars in 2012 to nearly 5.3 dollars on 12 January 2017, which consider as an administrative and accounting scandal (Peterson, 2017). Also, in Egypt, many questions raised by the participation of large audit firms (e.g., PWC) in the assessment of the government assets, which was less than its real value during privatization process (Dahi, 2012; Puddephatt, 2012). This provide an apparently influential setting to explore the impact of auditing firm size and auditors' ethical reasoning in Egypt. Furthermore, despite the results from the (ACFE., 2014) Report to the Nation on Occupational Fraud and Abuse, which show that external auditors in the Middle East detected no fraud cases and North Africa including Egypt, $33.3 \%$ of the fraud cases were detected by internal auditors.

Putting together, this study expects that as audit quality in Big 4 audit firms is derived more by litigation exposure and litigation exposure is considered as a form of punishment. This reasoning leads to the next hypotheses.

$\mathrm{H}_{2}:$ There is a negative relationship between ethical reasoning levels of auditors in Egypt and the size of auditing firm.

\subsection{Position of auditor}

With the outburst of a number of business scandals, increasing attention has been given to the auditors' position, particularly the audit principals and leaders role in determining ethical conduct. Previous research argues that behaviour of auditors as an element of the ethical culture shaped by leaders (Morris, 2014). An ethical leader is considered as a moral person who not only represents themselves as trustworthy and honest in their personal life, but likewise directs others in ethical facets by encouraging accountability, setting ethical standards and conveying ethical messages (Trevino and Brown, 2004).

Liu and Ren (2017) found that there is a significantly positive correlation between trainee auditors' likelihood of reporting client's irregularities and their perception of audit engagement team leader's ethical stance. Leaders can also positively influence the whistleblowing behavior within the organization by incorporating organizational justice in its whistleblowing policies and procedures (Seifert et al, 2010). Previous studies show how leader's role can affect, control, motivate, ethical orientation, and prevent unethical behavior in auditing firms. Many ddiscussions have centred on the 'tone at the top' as a driver of the ethical (or unethical) behaviour of accountants and 
auditors. For example, Tervo et al. (2014) found that auditors are influenced by the tone that the partner sets for the firm and by the working relationship that the auditor junior has with the supervising senior auditor. Also, Allen and Ng (2001) found that CPAs holding a higher financial stake in public accounting, namely partners, favoring banning referral fees and contingent fees significantly less than CPAs with a lesser stake. Also, there is a significant negative relationship between financial stake and moral reasoning. These results seem to suggest that self-interest among CPAs may influence their moral reasoning. Individuals who hold a higher position in audit firms are exposed to a higher risk than those with a lower position. Consequently, auditors in senior manager and partner positions tend to have lower ethical development than auditors in lower position (Armstrong, 1987; Ponemon, 1988, 1992; Ponemon and Gabhart, 1990). From that we consider that the levels of ethical reasoning of auditors in Egypt will be negatively correlated with auditors' positions. Thus, the third hypothesis is:

$H_{3}$ : There is a negative relationship between ethical reasoning levels of auditors in Egypt and the position of auditor.

\section{Research method}

\subsection{Sample}

A cross-sectional research design was employed to collect data from Egyptian auditors. Data was collected from auditors working in two Big 4 firms, two middle size firms, three small firms and CAO (The Central Auditing Organization) through a randomized survey.

Following Kassem (2018), a two-stage process was employed to obtain access to participants. First, the Big 4 firms were contacted via email or face-to-face and questioned to participate in our research. It was difficult to convince auditors; especially auditors working in the big offices to answer the test immediately or on the same day because of the work pressure, therefore the data has been collected over a period of several months. However, the researchers were not able to obtain answers from some of auditing offices (i.e., two firms) because they did not wish to administer the questionnaire to their staff. Two Big 4 firms only accepted to conduct our research with their auditors where some auditors' contacts were obtained. Then, to avoid any bias, the researchers decide to make the sample more comprehensive by including all kinds 
of auditing firms in Egypt. This sampling process yields two Big 4 firms, two middle size firms, three small firms and CAO.

The snowballing method was also employed to find more participants where existing contacts were invited to identify other potential contacts who might be interested to participate in the present study. Second, new contacts were created through LinkedIn and colleagues and they were then requested to complete the questionnaire. This led to a final sample of 232 participants. The questionnaire was initially tested by three external auditors who each have more than ten years of audit experience. This ensured that the wordings, structure and questions were well defined and logical. Previous to preliminary testing, five experienced academics were asked to comment on the suitability of the questionnaire. This assisted in creating content validity and reliability of data and enabling necessary amendments prior to preliminary testing. Positive feedback was received from the three external auditors with no change required.

Participants received a survey that requested them to complete the accounting ethical instrument (AEDI) to measure deliberative ethical reasoning. The participants were also asked to provide information about their job title, age, audit experience, type of audit office, age, marital status, education level, and position level. The survey also divided auditors into two categories, managers (partners, mangers and seniors) and juniors. We prepared 232 test sheets, which were personally distributed to the targeted auditing firms. A total of 178 completed questionnaires were returned and used as part of this study after a consistency check that has been recognized by Rest (1993) was utilized. The summary of sample procedures is presented in Table 2.

\section{INSERT TABLE 2 ABOUT HERE}

\subsection{Measure of auditors' ethical reasoning}

There are two versions of the audit-specific instrument: prescriptive and deliberative. Each version of the instrument is identical to the other except that each elicits one mode of the accountants' moral reasoning. The prescriptive version of the audit-specific instrument requests subjects to consider how auditors should ideally resolve the described dilemmas. The deliberative version of the audit-specific instrument requests participants to consider how auditors would realistically resolve the 
described dilemmas. According to Thorne (2000), the reliability and validity of the audit-specific instrument is comparable or better than that of the Defining Issues Test (DIT) of a similar length.

The testing of all three hypotheses rely on the AEDI test, to examine the ethical reasoning of each auditor. A T-test was then used to compare the mean values between groups. AEDI was used to test and measure deliberative reasoning only, which consists of a copy of six moral dilemmas. Each situation presented a short case about a person who had differing options to consider when trying to solve an ethical dilemma. Each scenario was followed by twelve questions and each participant selected four questions that were the most important from their perspective on the various situations and categorized them in a descending order. The twelve sets of questions express the stages of moral development. Then we collected the weights of the points selected by each participant. For both the fifth and sixth stages, express the post-conventional stage of moral development. This is the then divided it into the sum of the previous points and allocated to the elements of the fifth and sixth stages, thus reaching a level for each participant ranging from 0 to $100 \%$ (P-score), this score reflects the ethical development.

\subsection{The regression model}

To test the empirical validity of the hypotheses formulated above, we used an ordered logistic regression model. Ordered logistic regression is used because the dependent variable is a categorical variable (Chan and Leung, 2006). The following regression analysis is performed:

$\mathrm{ERL}=\alpha_{0}+\beta_{1}$ Audit firm size $+\beta_{2}$ Auditor position $+\sum_{i=1}^{4} \beta_{i}$ CONTROLS + $\varepsilon$

where,

\section{Dependent variable:}

$\mathrm{ERL}=$ Ethical reasoning level (categorical variable; 1 for Pre-conventional level, 2 for Conventional level, and 3 for Post -conventional level).

\section{Independent variables:}

Audit firm size $=($ categorical variable; 1 for small firms, 2 for Medium firms, 3 for Big firms, and 4 for $\mathrm{CAO}$ ). 
Auditor position $=$ position of auditor (dummy variable; 1 for managers and 0 for juniors).

\section{Control variables (CONTROLS)}

Education level = auditor education level proxied by a dummy variable: 1 if the auditor holds postgraduate certificate, 0 otherwise;

Age $=$ auditor age;

Audit experience $=$ the number of years for which the auditor has engaged in audit work; and

Gender $=$ auditor gender proxied by a dummy variable: 1 if the auditor is male, 0 if the auditor is female.

Previous studies reveal systematic relations between a number of demographic factors and the level of ethical reasoning or stages of Rest model. These demographic factors include the education level each participant had ,age, experience and gender (Musbah et al., 2016; Shaub, 1994; Thorne, 1999; Ponemon, 1990; Rest, 1986; Sorensen et al.,2017; Uyar and Gungormu., 2013; Bampton and Cowton, 2013).

\section{Results}

\subsection{Test of instrument validity and reliability}

The general alpha stability coefficient of the survey as a whole has a high coefficient of 0.82 , indicating the validity of the test used in the current study of the target sample. The reliability coefficient of the questionnaire is also high (0.91), indicating the possibility of relying on the survey questions in forming the results as shown in Table 3.

\section{INSERT TABLE 3 ABOUT HERE}

\subsection{Egyptian auditors' ethical reasoning}

Rest (1993) states that the level of the pre-conventional moral reasoning can be assessed as a $P$-score of $27 \%$ or under. While, the conventional level falls between $28 \%$ to $41 \%$, and the post-conventional level falls above $42 \%$. According to Table 4 , the mean value of the level of ethical reasoning to the full sample is $44.9 \%$. Thus, we reject Hypothesis 1, which states that the general ethical reasoning levels of auditors in Egypt does not fall in the post-conventional level. The results show that $13.07 \%$ of the auditors' level of ethical reasoning is concentrated at the pre-conventional level, 
followed by $15.91 \%$ at the conventional level and $71.02 \%$ at the post-conventional level. This suggests that majority of the Egyptian auditors are in the post-conventional level of ethical reasoning category. The auditors can be said to be at the postconventional level of Kohlberg's model where they no longer simply accept the values and norms of the group to which they individually belong. Instead, they try to understand each situation from the point of view that impartially considers everyone's interest. Their behavior is driven by universal ethical principles such as justice, rights and honesty.

Our results are similar to Al-aidaros (2014), and Jeffrey and Weatherholt (1996). For example, Jeffrey and Weatherholt (1996) finds that that majority of Taiwanese auditors are at the post-conventional level of moral reasoning. However, our results contradict the results of Haron et al. (2015) in a different developing country (Malaysia). The difference in the results of the studies indicates that there are other environmental factors, which can affect moral reasoning, not only the religious aspects, but the ethical implications do not always translate into the religious dimension of each decision. Therefore, the results imply that Egyptian professionals are considered to have high levels of ethical reasoning.

\section{INSERT TABLE 4 ABOUT HERE}

\subsection{Auditing firm size}

We recalculated the mean value of the results of the surveys based on auditor firm size in Table 5, to investigate the relation between ethical reasoning levels of Egyptian auditors and the size of auditing firm. The results show that the general ethical reasoning levels among auditors working in big and medium firms were 38.6\%, 39\% respectively (conventional level). While, small firms and CAO are classified as postconventional level (47.8\% and $53.3 \%$, respectively).

\section{INSERT TABLE 5 ABOUT HERE}

Additionally, we ran the ordered logistic regression analysis and results are presented in Table 6.

INSERT TABLE 6 ABOUT HERE 
The ordered logistic regression models are statistically significant (i.e. $P$-value $<$ $0.0001, P$-value $<0.0000$, respectively) and explain $10.08 \%$ and $15.30 \%$ of the variation in ethical reasoning level, respectively. The coefficients of the Audit firm size in Model 1 of Table 6 are negative $($ Coef $=-2.2588, p<0.001)$. This finding provides evidence that small and medium audit firms in Egypt are more ethical compare to Big4 and it supports past studies that reported similar findings (Ford and Richardson, 1994; Khurana and Raman, 2004; Sun and Liu, 2011). Therefore, Hypothesis 2 that states that there is a negative relationship between ethical reasoning levels of auditors in Egypt and the size of auditing firm is accepted. The results are contrary to (Espinosa-Pike and Barrainkua, 2016; Harron et al., 2014) and Naslmosavi et al. (2013) that small audit firms typically do not have formal in-house training which to rely on, so moral reasoning ability is not increased despite having 'practice' in resolving ethical dilemmas. Therefore, these practitioners always rely on personal interpretation of what is the right decision, and factors such as experience, education, skills and employee competence have influence on the formation of auditor's ethical opinion.

Our results support Khurana and Raman (2004) and Sun and Liu (2011), which suggest that litigation exposure and brand name reputation protection drive perceived audit quality in the Big 4 audit firms. Particularly, litigation is likely to be more costly for these firms in terms of the potential impairment to their brand name and reputational capital in which they have invested more (Palmrose 1988). The results indicate that the size of auditing firm can have a negative effect on the ethical reasoning of auditors in Egypt, and factors like experience, skills and education do not always translate in ethical considerations. However, it highlights the importance of developing the ethical reasoning of the auditor in the large and medium firms, and calls for further research on the impact of the size of auditing firm on the ethical reasoning of the auditor in Egypt.

Additionally, we ran the model again after excluding CAO observations and results are presented in Model 2 of Table 6. These results are similar to those reported in Model 1 of Table 6.

\subsection{Auditor current position}

Table 7 shows the results after we recalculated the mean value of the surveys based on auditor position (i.e., managers vs. junior auditors) to examine the effect of the 
auditors position on their ethical reasoning in different firms. The results show that there is a negative relationship between ethical reasoning levels and the position of auditor.

In fact, the results are similar to previous studies (Armstrong, 1987; Ponemon, 1988, 1990, 1992; Ponemon and Gabhart, 1990). This implies that auditors who are in more senior or partner positions tend to have lower ethical development than auditors do in lower positions. On the other hand, auditors in the Central Auditing Organization (CAO) in Egypt have the highest level of ethical reasoning when compared to auditors in similar positions at other auditing firms. This indicates the ability of this public organization to develop the ethical reasoning from the top management to the lower departments and maintain a high moral culture within the institution. These results are unique. The CAO in Egypt is not affiliated with the state, but is affiliated directly to the president of Egypt, which monitors the work of the state and the public sector in Egypt $\underline{(\mathrm{CAO}, 1988)}$. The CAO performs a mandatory auditing on all companies, when the Egyptian government own at least $25 \%$ of its shares, according to Article 3 of Law No. 144/1988. These results shed light on how independence may moderate the relationship between ethical reasoning and auditor position.

\section{INSERT TABLE 7 ABOUT HERE}

Table 8 shows the "T" test used to compare the level of ethical reasoning of the audit managers and the junior auditors.

\section{INSERT TABLE 8 ABOUT HERE}

Also, the results in Table 5 support the primary results reported in Tables 7 and 8 . The coefficients of the Auditor position in Table 6 are negative $($ Coef $=-1.4895, p<$ 0.01). This finding provides evidence that auditors in senior manager or partner positions tend to have lower ethical development than auditors do in lower positions. This supports previous studies that reported similar findings (Armstrong, 1987; Ponemon, 1988, 1992; Ponemon and Gabhart, 1990; Tervo et al., 2014). Therefore, Hypothesis 3 that states that there is a negative relationship between ethical reasoning levels of auditors in Egypt and the position of auditor is accepted. 
Additionally, we ran the model again after excluding CAO observations and results are presented in Model 2 of Table 6. These results are similar to those reported in Model 1 of Table 6 . In addition, this result is more significant because the coefficient increased to -2.6437 .

\section{Discussion}

This study measures ethical reasoning and its role in the development of professional performance of the auditors in Egypt. The results indicate that the level of ethical reasoning of auditors in the large and medium auditing firms in Egypt is classified at the conventional level. This implies there is work to be done to raise the level of ethical reasoning in these firms to reach the required levels in accordance with professional standards. The findings are consistent with previous studies, which indicate that general level of ethical reasoning among accountants compare to other professionals is low in many countries (Bampton and Cowton, 2013). However, auditors belonging to small firms and $\mathrm{CAO}$ were more developed in the deliberative ethical reasoning. CAO is an independent entity that is affiliated with the president of Egypt directly. It mainly aims at controlling the state funds and the funds of other public entities. Thus, auditors tend to have independent reasoning, and therefore are not subjected to pressures of clients like other audit firms.

Interestingly, the level of ethical reasoning of the juniors in the profession of auditing was higher than managers and seniors in all auditing firms (small, medium, big), except for auditors in CAO as shown in Fig 1.

\section{INSERT Fig 1 ABOUT HERE}

This finding is consistent with some studies (e.g. Ponemon, 1990, 1992; Elias, 2002) that find junior members of staff levels of moral reasoning is higher than senior staff in auditing firms. This implies that the more experienced and higher paid auditors are less sensitive to ethical issues than their younger counterparts are. Similarly, extant research has also found lower moral reasoning ability amongst higher-ranked CPAs and CMAs outside auditing firms (Ponemon and Gabhart, 1993, Eynon et al., 1997). Finally, the aim of this research is to investigate Egyptian auditors ethical reasoning, to understand whether auditors' ethical reasoning is influenced by audit firm size or/and 
auditor position using a single equation model. Future studies may develop multiple variable circular causation interrelations (fully endogenous inter-variable relationship) model to gain more analytical and institutional implications. Previous studies (e.g., (Choudhury, 2011, 2014; Choudhury et al., 2011, 2014; Choudhury and Syafri Harahap, 2008) argue that analytical and institutional implications would be conveyed by the estimated coefficients of circular causation interrelations. Such causation interrelationships strongly enhanced the interaction, integration and evolutionary learning and highlight the nature of the present interrelations among the intercausal variables (Choudhury, 2011, 2014; Choudhury and Syafri Harahap, 2008).

\section{Conclusion}

This study examined the nature of the ethical reasoning of auditors in Egypt, and aims to understand whether the levels of ethical reasoning is influenced by audit firm size or/and auditor position. This investigation has not been conducted in the Egyptian environment before to our knowledge.

This study found that the level of ethical reasoning of auditors in Egypt generally was at the post-conventional level, which indicates the ability of the auditors to meet the ethical requirements of the profession. However, the levels of ethical reasoning were at the conventional-levels in the large and medium firms, which indicates the importance of developing levels of ethical reasoning for practitioners in these firms. On the other hand, the results show that the levels of ethical reasoning were at the postconventional level in both small firms and the Central Auditing Organization. The study found that the juniors were more sophisticated in the levels of ethical reasoning than the audit managers in the sample, except for the Central Auditing Organization, which indicates the ability of this entity to maintain the strong levels of ethical reasoning at all levels. One of the main findings of the research is that auditors who are employed by government auditing institutions are better at being able to maintain higher levels of ethical reasoning than private firms are and as a result of higher levels of ethical reasoning in higher management, and the tone of the top considered to be more ethical. Possibly, this is due to the lack of external pressure that can be expressed by clients over auditors.

Noticeably, this study has significant policy, practitioner, and regulatory implications in emerging markets that are expecting or currently pursuing auditing 
reforms. It is important to measure ethics periodically in developing countries environment to determine the extent to which practitioners meet the ethical requirements of the internationally accepted standards and codes of best practice. It is also essential to deepen the study in this field to include more firms and more diverse sample. In addition, more focus should be placed on understanding how CAO continue to maintain strong level of ethical reasoning across their practice.

It should be pointed out that this study like other previous studies as Bampton and Cowton (2013) is cross-sectional rather than longitudinal. One of the caveats of crosssectional studies is that it can be difficult to identify the reason for a phenomenon, so it should not be inferred that individuals necessarily suffer a reduction in their ethical reasoning abilities as they progress in their career. Rather, it is possible that those with higher levels of moral reasoning leave the profession for various reasons. Finally, future studies should explore determinants of ethical reasoning among CAO auditors. As the authors cannot argue that $\mathrm{CAO}$ auditors responses to ethical scenarios is only affected by ethical reasoning. CAO auditors are public officers and are in a much riskier position if they failed to discover or report an accounting irregularity and/or scandal. Furthermore, they audit governmental entities and their citizenship and sense of responsibility could drive how strictly they behave with clients. 


\section{Appendix}

\section{AEDI developed by Thorne (2000) Examples of the Audit and Corporate Ethical Scenarios}

I have the honor to inform you that you have been selected randomly in a research sample which aims to study the level of ethical reasoning of auditors in Egypt. This survey is part of this study, which aims to understand the nature of the ethical reasoning of the auditor in Egypt and the extent to which the requirements of the professional constitution for the profession of accounting and auditing are met, which ultimately improve the professional performance of the auditor in Egypt

We ask you to write your own data first, then answer the six dilemmas that the auditor may be exposed to during the performance of his profession, without prejudice or exaggeration

Dear Sir / Madam Please write the following information in full

\begin{tabular}{|l|l|}
\hline Office: & \\
\hline Name: & \\
\hline Position: & \\
\hline Gender: & \\
\hline Religion: & \\
\hline Age: & \\
\hline
\end{tabular}




\section{AEDI developed by Thorne (2000) Examples of the Audit and Corporate Ethical Scenarios}

\section{1- $\quad$ Alice and the ABC Company}

Alice is a senior auditor and CPA for a national CPA firm that provides auditing, tax, and consulting services. The firm has developed a package called the ACME Accounting System, which is sold to the general public as well as the firm's clients. Alice is the auditor in charge of the fieldwork on the ABC Company, Inc. audit. During the course of this audit assignment, Alice is asked to evaluate the quality control of the accounting system, which happens to be the ACME package. Alice uncovers several severe control weaknesses in the ACME system. Before rendering the management letter to $\mathrm{ABC}$ management, Alice is told by her boss to modify the negative comments regarding the ACME package. Realistically, should Alice amend the management letter? (Check one.)

In the process of advising Alice whether she should amend the management letter, many items need to be considered. Below is a list of some of these items. Please indicate the importance of each of the following considerations:

\section{importance}

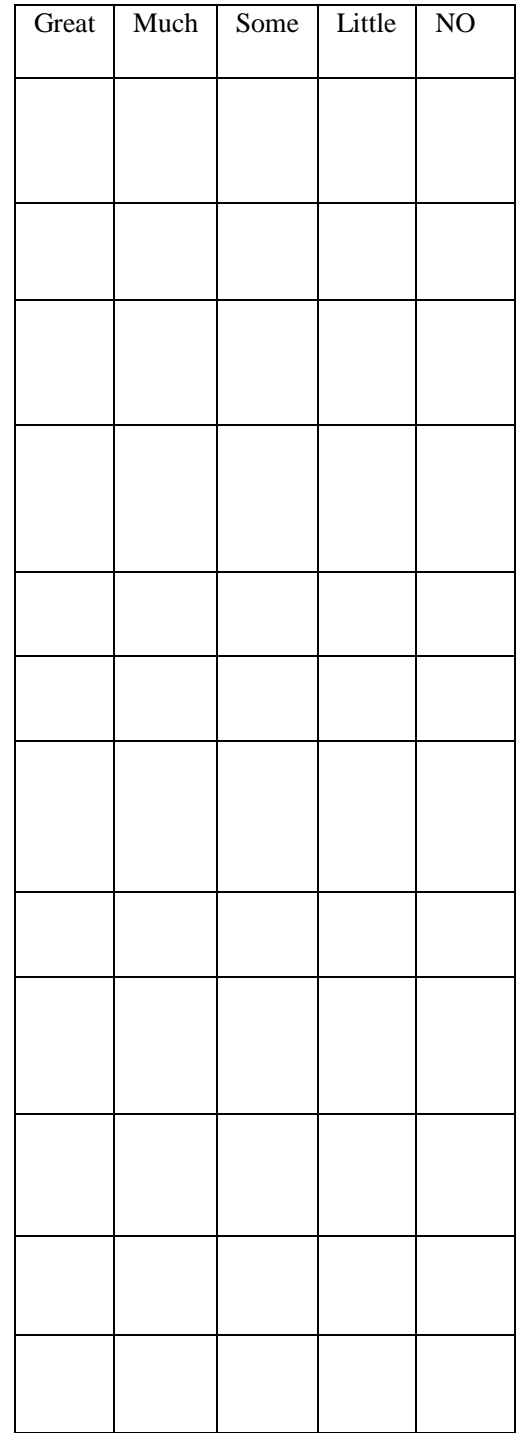

1. Whether the weakness in the ACME system may be easily remedied by compensating controls?

2. Would a good employee defer to her supervisor's judgment?

3. Whether Alice's job may be threatened by her refusal to revise the letter.?

4. Whether fair deliberation on the client's financial position can predict professional reputation?

5. What is best for Alice's firm?

6. Whether Alice has a duty to ensure the management letter is accurate?

7. What is the potential value of an independent audit in lieu of society's current perspective on an enterprise's net worth?

8. How is society best served?

9. Whether clients really care about internal control or if all they ever really want is a clean audit opinion?

10. Would amending the management letter be consistent with what Alice thinks is right?

11. What action would Alice's peers in the audit firm expect her to make?

12. What factors are relevant in determining Alice's professional responsibility?

From the list above, rank the four items of greatest importance to a "realistic" response:

Most Important ------- 2nd Most Important ------- 3rd Most Important--------- 4th Most Important 


\section{2- Susan and Cambridge real-Estate}

Susan is a CA and the partner on the Cambridge Real -Estate audit . it is a privately controlled company and her firm's largest client . the relationship between Cambridge's and Susan's firm has seriously deteriorated over the last two years . as has Cambridge's profitability . a contentious issue has emerged from this year's annual audit . the proposed estimate for uncollectible receivables . as included by management on the financial statements . is understated by an amount Susan considers material . the client is unwilling to budge on this issue . the CEO of Cambridge feels that it is merely a difference of professional opinion regarding the adequacy of an estimate . he feels that his own staff has specialized knowledge of the client base which renders their estimate of collectability more reliable than estimates formulated by the audit staff . Cambridge needs a clean audit opinion in order to extend its line of credit at the bank. Susan's firm has a strong desire not to lose the client .

Realistically, should Susan concede this issue ? (check one)

----- Yes

------ Can't decide

$------N o$

In the process of advising Susan weather she should amend the management letter . many items need to be considered . below is a list of some of these items . please indicate the importance of each of the following considerations:

\section{Importance}

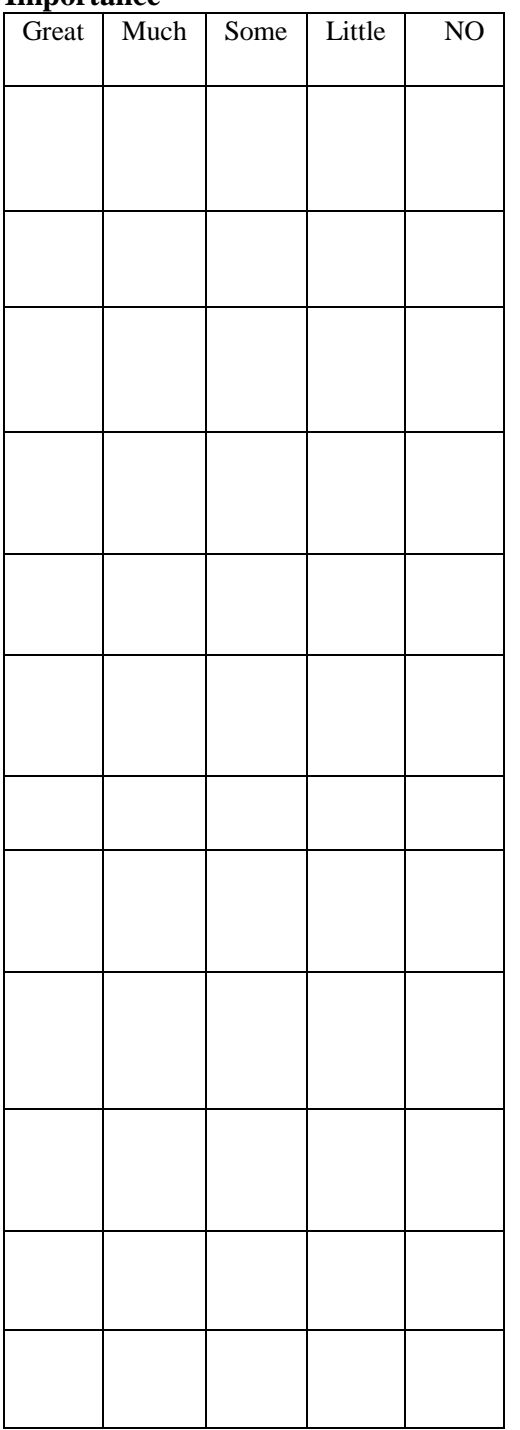

1- $\quad$ How other firms in the industry estimate uncollectible receivables

2- Would a good auditor require his/her client to revise the estimate of uncollectable receivables?

3- Weather the threat from the client has substance ?

4- Weather the client's position would be considered reasonable by an independent assessment and by society in general?

5- Weather the essence of professional judgment over whelms the advocation of isomorphism?

6- Weather Susan's decision would in any way violate the right of users or potential users of financial statements ?

7- What is the best interest of Susan's firm?

8- Is Susan more responsible to the bank or to her audit client?

9- $\quad$ Does an auditor have an obligation to ensure specified accounting standards are followed . regardless of circumstances?

10- What values has Susan set out for herself in her own personal standards of behavior?

11- What factors are relevant in the determination of Susan's total responsibility to society?

12- What position will be taken by the other partner of the firm ?

From the list above , rank the four items of greatest importance to a "realistic" response :

-----most important
$----2^{\text {nd }}$ most important $3^{\text {rd }}$ most important

------ $4^{\text {th }}$ most important 


\section{3- Bill and Dogwood Construction}

Bill is a staff auditor and CA for a small firm that provides auditing services . the president of the Dogwood Construction Corporation is searching for a chief financial officer . and has asked Bill to help recruit and select an appropriate candidate. Bill is the " in charge " auditor on the Dogwood engagement . which is among the largest and most profitable jobs for the firm. Bill truly believes that he can provide a valuable service to Dogwood . as well as his firm , by performing the function . in addition . Bill already knows an individual , a personal friend who has the right qualifications for this very important position .

Realistically, should Bill assist Dogwood's president ?(check one)

$$
\text { ------ should assist him -------- Can't decide -------should not assist him }
$$

In the process of advising Bill weather he should assist Dogwood's president . many different many issues need to be considered . below is a list of some of these issues . please indicate the importance of each of the following considerations:

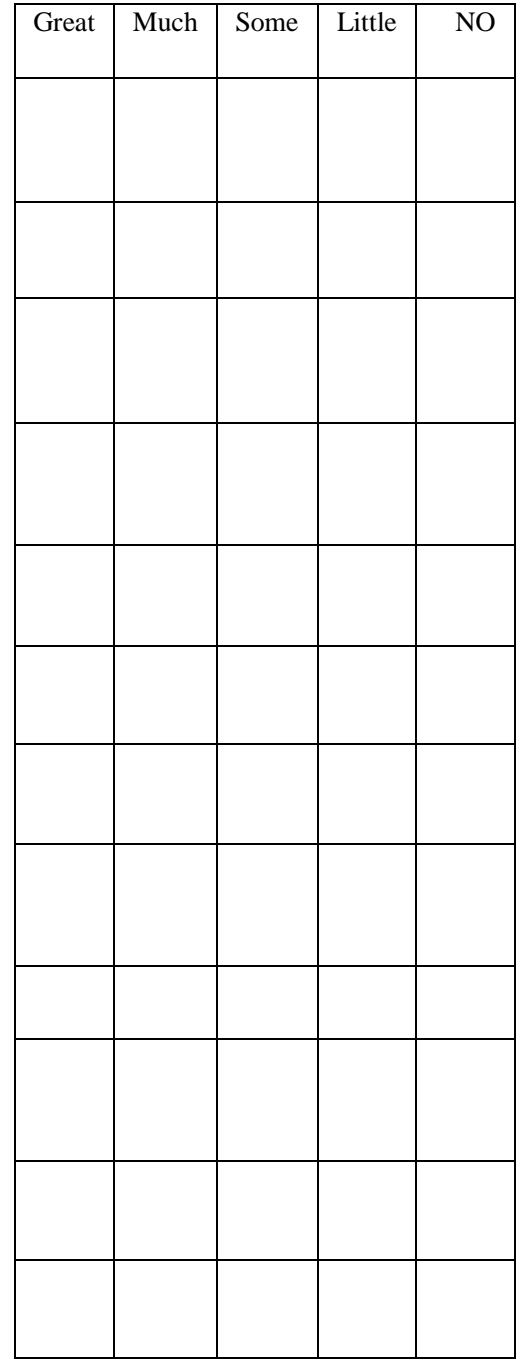

1- What effect will Bill's refusal have on his firm's relationship with the client?

2- Weather Bill has the right to assist a client in the selection and recruitment of a chief financial officer?

3- Weather employment referrals ought to be in the hands of a few greedy headhunters?

4- Does telling his friend the job is available constitute an infringement of Bill's professional responsibilities?

5- $\quad$ Will having a friend as the chief financial officer prevent Bill from making a fair assessment on the firm's financial position in the future ?

6- Weather bill is overweight or has a weakness for fast food?

7- Weather the audit partner of the Dogwood audit will endorse Bill's actions?

8- Would a good auditor refuse to assist Dogwood's president?

9- What actions would Bill's friend expect him to take?

10- Would it be fair to other clients if Bill assisted Dogwood's President?

11- Would assisting the president in any way violate the rights of others?

12- Would refusing to assist the president be consistent with what Bill thinks is right?

From the list above , rank the four items of greatest importance to a "realistic" response :

-----most important
$-----2^{\text {nd }}$ most important

------ $3^{\text {rd }}$ most important 


\section{4-John and the folders Audit}

John is the senior CA in charge of the field work for two legally unrelated audit clients : the folders company and Colby corporation .while on the folders job, john learns that Colby is the only supplier of a product that is critical to the manufacturing of folders' final output . the next day, john learns from Colby management that there are greatly increasing the price of their primary products , and the new pricing policy can bankrupt folders . john knows that folders recently considered the acquisition of a small company in Asia that, with some effort, can redirect its production to produce a product similar to the one made by Colby . however, the estimated unit cost was greater than the present ( known and assumed stable ) prices offered by Colby .based on their limited information .folders did not seriously consider the purchase of this small company .

Realistically, should John disclose Colby's plans to folders ? (check one )

$$
\text { ------- should assist him -------- Can't decide } \quad \text {--------should not assist him }
$$

In the process of advising john weather he should disclose colby's plans to folders, many different items need to be considered . below is a list of some of these issues . please indicate the importance of each of the following considerations:

Importance

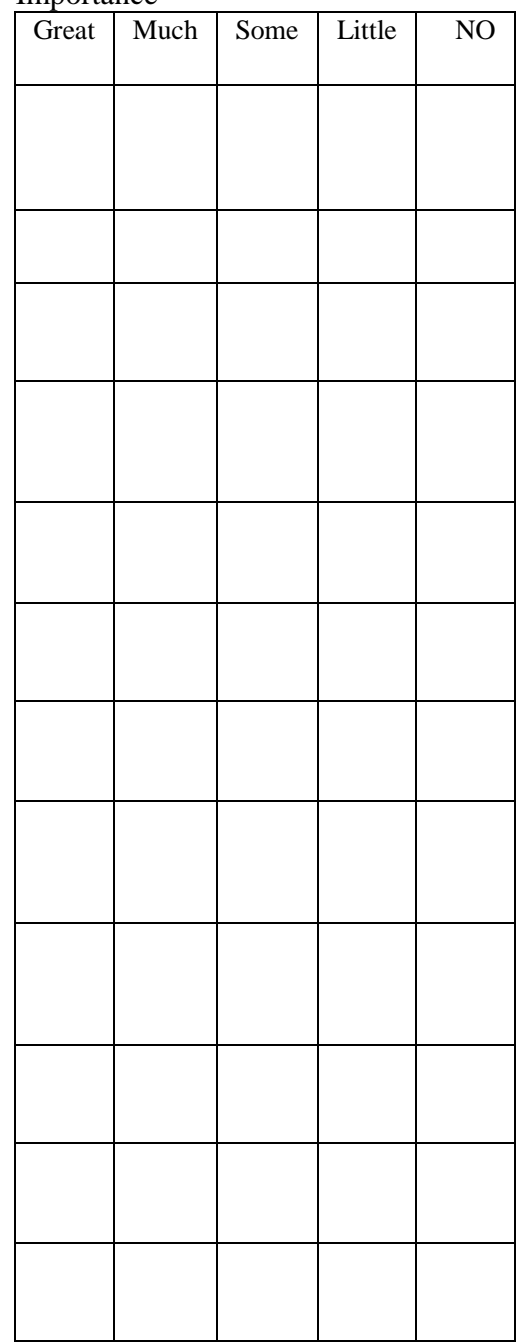

1- Is john obliged to maintain client confidentiality regardless of circumstances?

2- Whether the partner on the audit will endorse john's actions?

3- What is the best for the reputation of John's firm?

4- Whether folders reliance on a single supplier is disclosed in the financial statements?

5- Whether client confidentiality is the ultimate prelude to the necessity of rendering of an adult opinion?

6- Which course of action will bring about the greatest good for all the society?

7- How will John's actions be perceived by others in the audit firm?

8- Whether the folders company brought this upon itself by relying solely upon one supplier?

9- Whether John's actions are against regulatory standards with respect to insider information?

10- What values are the basis for determining which stake holder's interest takes precedence when they conflict?

11- Would John's actions be consistent with what he believes is just?

12- $\quad$ Whether the reputation of the audit profession will suffer if folders goes bankrupt?

From the list above, rank the four items of greatest importance to a "realistic" response :

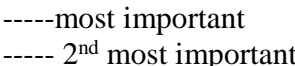

$3^{\text {rd }}$ most important

$-----4^{\text {th }}$ most important 


\section{5- Bob and Cora limited}

Bob is a brand new partner in a medium-sized audit firm . Bob has inherited a substantive book of business as a result of the unanticipated demise of one of the firm's founders . in fact .Bob has had the good fortune to have been granted the audit of the firm's largest and oldest client .Cora limited . and its 70 percent owned subsidiary . Corinne incorporated .Bob discovers that Cora limited has historically been charging an exorbitant management fee to Corinne incorporated . Bob is concerned that the interests of minority shareholders of Corinne incorporated are materially compromised by such an arrangement . in discussions with the client, Bob learns that this procedure was undertaken several years ago upon the advise of his own firm's tax department . this procedure is used to boost Cora's earning to take advantage of significant tax savings that would otherwise be lost to Cora limited .Cora's management is not amenable to losing these tax savings. The magnitude of all related party transactions between Cora limited and Corinne incorporated are disclosed in the financial statement as required by the accounting standards .consequently, submits Cora's management . the financial statement of Cora limited and Corinne incorporated are fairly presented .

Realistically, should Bob insist on separate disclosure of the management fee by Cora Limited ? (check one )

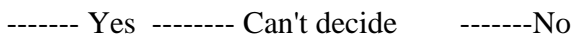

In the process of advising Bob on whether he should Insist that Cora disclose the management fee , many different issues need to be considered . below is a list of some of these issues . please indicate the importance of each of the following considerations:

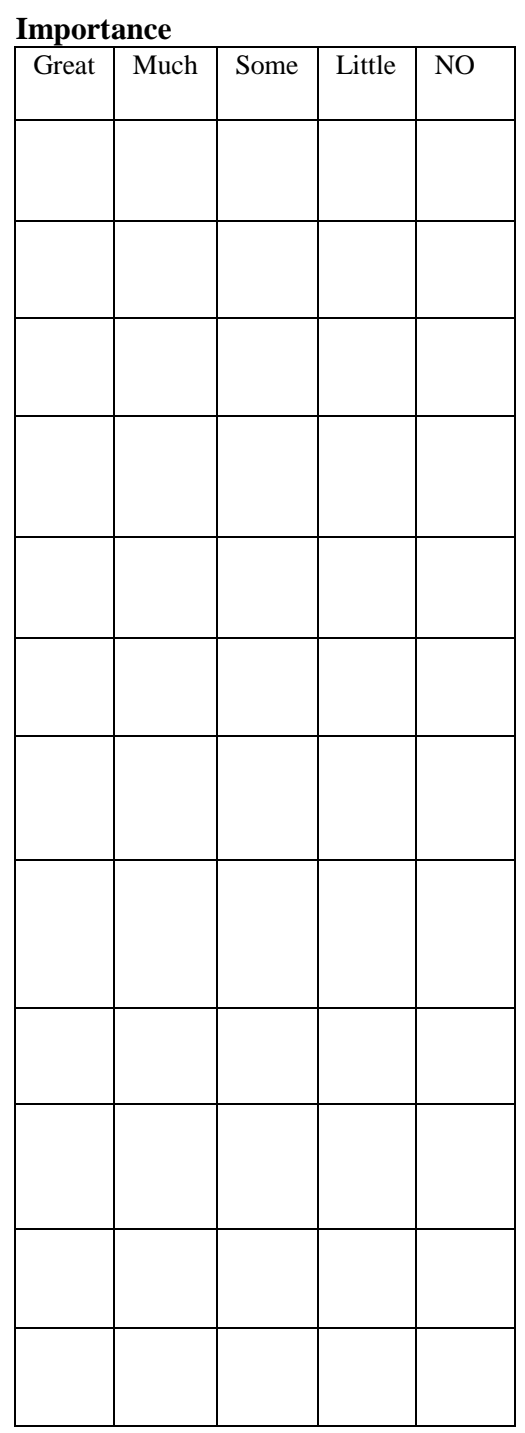

"realistic" response :
1- Whether other partners in the firm will support Bob's position?

2- Would it be fair to the tax department if Bob did not insist that the management fee be disclosed?

3- Whether anybody really cares about GAAP in their efforts to exploit everyone else?

4- Whether a retroactive adjustment to the financial statements is required?

5- Whether disclosure of the management fee would benefit more people to a greater extent?

6- What is the quintessence of an audit apart from displacement , especially for minority shareholders?

7- Is Bob obliged by professional standards to assess the reasonableness of management fee?

8- Whether it is generally accepted that firms manipulate the amount of management fees between associated companies to minimize their tax liability?

9- What is the financial importance of the Cora audit to Bob's firm ?

10- Does Bob have a professional duty to protect the right of minority shareholders ?

11- Would Bob's decision be consistent with his own personal beliefs

12- What values are the basis for governing fair presentation when specific accounting standards do not result in full disclosure?

From the list above, rank the four items of greatest importance to a -----most important
----- $2^{\text {nd }}$ most importan $3^{\text {rd }}$ most important

$4^{\text {th }}$ most important 


\section{6- Alex and Big Boulder Beer}

Alex is the partner on the Little Rock Brewing Company audit . Little Rock Brewing Company is a wholly owned subsidiary of big boulder beer manufacturing. The entire audit of the big boulder consolidated entity is handled by different offices of Alex's firm and nearing completion. The audit of Little Rock Brewing Company proceeded without a hitch . Nevertheless, Alex is troubled. Alex is aware that several sites of Big Boulder Beer have not been visited by audit staff and the soon -to-be -released .consolidated financial statements of Big Boulders do not show that the plants at these sites are out of operation. The financial statements carry these plants at their historic cost . subject to normal depreciation provisions.Alex feels that the asset write - down "impairment " of the unused plants cannot be dismissed as temporary or immaterial to the consolidated entity . these concerns have been discussed with the audit partner of The Big Boulder Beer who has indicated that this issue is not Alex's concern . The senior partner of Alex's office also has advised Alex that this matter is not Alex's responsibility .

Realistically. should Alex pursue the issue ? (Check one )

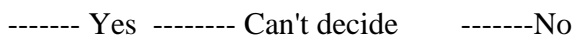

In the process of advising Alex on whether he should or should not pursue the issue, many different issues need to be considered . below is a list of some of these issues . please indicate the importance of each of the following considerations:

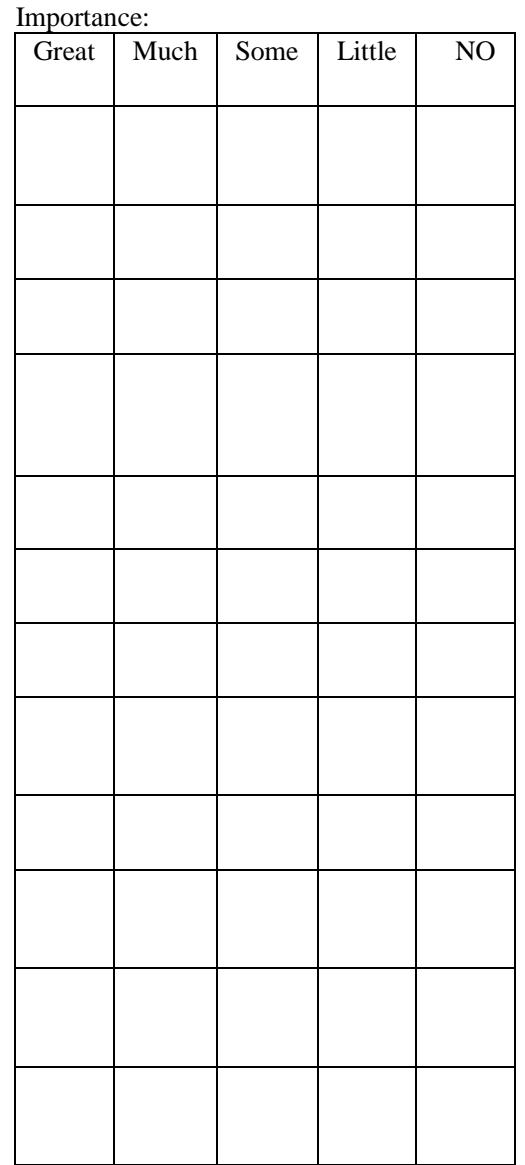

1. Does signing the audit report for Little Rock have anything to do with the Big Boulder issue?

2. What is in Alex's best interest ?

3. Whether the managing partner of Alex's firm will support Alex's actions?

4. Does Alex's sovereignty juxtapose the articulation of a cognizant response in opposition to the partner - in - charge of the consolidated enterprise?

5. Whether Alex should respect his superiors' decision?

6. Whether Alex more responsible to his firm or to his audit client ?

7. Whether Alex is a peer lover or prefers wine to peer ?

8. What values has Alex set out for himself in his own personal code of behavior?

9. Whether a system which supports powerful, opportunistic, and greedy organizations ought to be completely overhauled?

10. Does society expect Alex's responsibility to extend beyond the Little Rock audit ?

11. What a good partner bring this matter to the attention of other partners in the firm?

12. How is the public good best served?

From the list above, rank the four items of greatest importance to a "realistic" response :

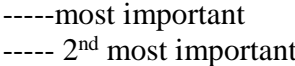

$3^{\text {rd }}$ most important

$4^{\text {th }}$ most important 


\section{References}

Abd-Elsalam, O.H. and Weetman, P. (2003). Introducing International Accounting Standards to an emerging capital market: relative familiarity and language effect in Egypt. Journal of International Accounting, Auditing and Taxation, 12(1), pp.63-84.

Abdolmohammadi, M. J., Read, W. J., \& Scarbrough, D. P. (2003). Does selection-socialization help to explain accountants' weak ethical reasoning?. Journal of Business Ethics, 42(1), 71-81.

Accountability state authority of Egypt (CAO), (1988), law and work regulation, www.cma.gov.eg.

Adhikariparajul, M., Hassan, A., Fletcher, M., \& Elamer, A. A. (2019). Integrated reporting in UK higher education institutions. Sustainability Accounting, Management and Policy Journal, Forthcoming. doi:10.1108/SAMPJ-03-2018-0093

Association of Certified Fraud Examiners. (2014). Report to the Nations on Occupational Fraud andAbuse. Retrieved from www.acfe.com Retrieved at 01/02/2015.

Al-Aidaros, A. H., Ghani, A. A., \& Idris, K. M. (2014). The Consistency Between Prescriptive and Deliberative Accountants' Moral Reasoning: Case In Yemen. International Review of Management and Business Research, 3(4), 1797.

ALBeksh, H. M. (2016). Compliance of Auditors to Ethics and Rules of Professional Conduct and Its Impact on Audit Quality. Imperial Journal of Interdisciplinary Research, 2(12).

Alnabsha, A., Abdou, H. A., Ntim, C. G., \& Elamer, A. A. (2018). Corporate boards, ownership structures and corporate disclosures: Evidence from a developing country. Journal of Applied Accounting Research, 19(1), 20-41.

Alshbili, I., Elamer, A. A., \& Beddewela, E. (2019). Ownership types, corporate governance and corporate social responsibility disclosures: Empirical evidence from a developing country. Accounting Research Journal, Forthcoming. doi:10.1108/ARJ-03-2018-0060

Arfaoui, F., Damak-Ayadi, S., Ghram, R., \& Bouchekoua, A. (2016). Ethics Education and Accounting Students' Level of Moral Development: Experimental Design in Tunisian Audit Context. Journal of business ethics, 138(1), 161-173.

Elmagrhi, M. H., Ntim, C. G., Elamer, A. A., \& Zhang, Q. (2019). A study of environmental policies and regulations, governance structures and environmental performance: The role of female directors. Business Strategy and the Environment, 28(1), 206-220.

Allen, P. W., \& Ng, C. K. (2001). Self interest among CPAs may influence their moral reasoning. Journal of Business Ethics, 33(1), 29-35.

Appelbaum, S. H., Deguire, K. J., \& Lay, M. (2005). The relationship of ethical climate to deviant workplace behaviour. Corporate Governance: The international journal of business in society, 5(4), 43-55.

Ardelean, A. (2013). Auditors' ethics and their impact on public trust. Procedia-Social and Behavioral Sciences, 92, 55-60.

Armstrong, M. B. (1987). Moral development and accounting education. Journal of Accounting Education, 5(1), 27-43.

Armstrong, M. B. (1993). Ethics and professionalism in accounting education: A sample course. Journal of Accounting Education, 11(1), 77-92.

Arnold Sr, D. F., Dorminey, J. W., Neidermeyer, A. A., \& Neidermeyer, P. E. (2013). Internal and external auditor ethical decision-making. Managerial Auditing Journal, 28(4), 300322. 
Arnold, D. F., \& Ponemon, L. A. (1991). Internal auditors' perceptions of whistle-blowing and the influence of moral reasoning: An experiment.

Bailey, C. D., Phillips Jr, T. J., \& Scofield, S. B. (2005). Does "political bias" in the DIT or DIT-2 threaten validity in studies of CPAs?. Behavioral Research in Accounting, 17(1), 23-42.

Bailey, C. D., Scott, I., \& Thoma, S. J. (2010). Revitalizing accounting ethics research in the neo-Kohlbergian framework: Putting the DIT into perspective. Behavioral Research in Accounting, 22(2), 1-26.

Baïada-Hirèche, L., \& Garmilis, G. (2016). Accounting professionals' ethical judgment and the institutional disciplinary context: A French-US comparison. Journal of business ethics, 139(4), 639-659.

Bay, D. (2002). A critical evaluation of the use of the DIT in accounting ethics research. Critical Perspectives on Accounting, 13(2), 159-177.

Bernardi, R. A., \& Arnold Sr, D. F. (1997). An examination of moral development within public accounting by gender, staff level, and firm. Contemporary Accounting Research, 14(4), 653-668.

Berisha, G., \& Shiroka Pula, J. (2015). Defining Small and Medium Enterprises: a critical review. Academic Journal of Business, Administration, Law and Social Sciences $1(1), 17-28$.

Blay, A. D., Gooden, E. S., Mellon, M. J., \& Stevens, D. E. (2016). Can Social Norm Activation Improve Audit Quality? Evidence from an Experimental Audit Market. Journal of Business Ethics, 1-18.

Bampton, R., \& Cowton, C. J. (2013). Taking stock of accounting ethics scholarship: A review of the journal literature. Journal of business ethics, 114(3), 549-563.

Burks, B. D. (2007). The impact of ethics education and religiosity on the cognitive moral development of senior accounting and business students in higher education (Doctoral dissertation, Nova Southeastern University).

Chan, S. Y., \& Leung, P. (2006). The effects of accounting students' ethical reasoning and personal factors on their ethical sensitivity. Managerial Auditing Journal, 21(4), 436457.

Choi, J. H., Kim, C., Kim, J. B., \& Zang, Y. (2010). Audit office size, audit quality, and audit pricing. Auditing: A Journal of practice \& theory, 29(1), 73-97.

Choudhury, M. A. (2011). Islamic economics and finance: An epistemological inquiry. Howard House, Wagon Lane, Bingley BD16 1WA, UK: Emerald Group Publishing.

Choudhury, M. A. (2014). Tawhidi Epistemology and its Applications: Economics, Finance. Science Society. Newcastle upon Tyne, UK: Cambridge Scholars Publishing.

Choudhury, M. A., Al-Muharrami, S., \& Ahmed, M. S. (2014). A circular causation model of the oil and gas sector relative to the non-oil sector in the Sultanate of Oman. International Journal of Management Studies, 21(2), 21-48.

Choudhury, M. A., Hossain, M. Z., \& Hossain, M. S. (2011). Estimating an ethical index of human wellbeing. The Journal of Developing Areas, 45(Fall), 375-409.

Choudhury, M. A., \& Syafri Harahap, S. J. M. F. (2008). Interrelationship between Zakat, Islamic bank and the economy: A theoretical exploration. Managerial Finance, 34(9), 610-617.

Chow, C. W., Massey, D. W., Thorne, L., \& Wu, A. (2014). A Qualitative Examination of Auditors' Differing Ethical Characterizations Across the Phases of the Audit 2 Data 
availability: Because of the need to preserve respondents' anonymity, data requests will be considered on a case-by-case basis. In Research on professional responsibility and ethics in accounting (pp. 97-138). Emerald Group Publishing Limited.

Christensen, A. L., Cote, J., \& Latham, C. K. (2016). Insights regarding the applicability of the defining issues test to advance ethics research with accounting students: A metaanalytic review. Journal of Business Ethics, 133(1), 141-163.

Clark, J. W., \& Dawson, L. E. (1996). Personal religiousness and ethical judgements: An empirical analysis. Journal of Business Ethics, 15(3), 359-372.

Cohen, J. R. (1997). Flexible scheduling in public accounting. Journal of Accounting Education, 15(1):145-158.

Cohen, J., Pant, L., \& Sharp, D. (1993). A validation and extension of a multidimensional ethics scale. Journal of Business Ethics, 12(1), 13-26.

Comprix, J., \& Huang, H. (2015). Does auditor size matter? Evidence from small audit firms. Advances in accounting, 31(1), 11-20.

Dahi, O. S. (2012). The political economy of the Egyptian and Arab revolt. IDS Bulletin, 43(1), 47-53.

Doyle, E., Hughes, J. F., \& Summers, B. (2013). An empirical analysis of the ethical reasoning of tax practitioners. Journal of Business Ethics, 114(2), 325-339.

EFSA (2016). Enforcement in auditors oversight board. http://www.fra.gov.eg /jtags/efsa_ar /proc_results_auditors.jsp?start $=1 \&$ size $=20 \& n$ Pages $=1 \&$ Year $\&$ fbclid $=$ IwAR0lyVkdk eSbNHXiSjYUqevRTquWuM7UKv_ef1_M42gZsdy9M5JUNfiOlhM

Elbayoumi, A. F., Awadallah, E. A., \& Basuony, M. A. (2019). Development of Accounting and Auditing in Egypt: Origin, Growth, Practice and Influential Factors. The Journal of Developing Areas, 53(2), 205-220.

El-Dyasty, M.M. (2017). "Audit market in Egypt: An empirical analysis". Available at SSRN: https://ssrn.com/abstract=3002783 or http://dx.doi.org/10.2139/ssrn. 3002783.

Elamer, A. A., AlHares, A., Ntim, C. G., \& Benyazid, I. (2018). The corporate governancerisk-taking nexus: Evidence from insurance companies. International Journal of Ethics and Systems, 34(4), 493-509.

Elamer, A. A., \& Benyazid, I. (2018). The impact of risk committee on financial performance of UK financial institutions. International Journal of Accounting and Finance, 8(2), 161-180.

Elamer, A. A., Ntim, C. G., Abdou, H., Zalata, A., \& Elmagrhi, M. H. (2019). The impact of multi-layer governance on bank risk disclosure in emerging markets: The case of Middle East and North Africa. Accounting Forum, Forthcoming.

Elamer, A. A., Ntim, C. G., \& Abdou, H. A. (2017). Islamic governance, national governance, and bank risk management and disclosure in MENA countries. Business \& Society, Forthcoming. Doi: 10.1177/0007650317746108

Elias, R. Z. (2002). Determinants of earnings management ethics among accountants. Journal of Business Ethics, 40(1), 33-45.

Emler, N., \& Stace, K. (1999). What does principled versus conventional moral reasoning convey to others about the politics and psychology of the reasoner?. European Journal of Social Psychology, 29(4), 455-468.

Emler, N., Renwick, S., \& Malone, B. (1983). The relationship between moral reasoning and political orientation. Journal of Personality and Social Psychology, 45(5), 1073-1080.

Espinosa-Pike, M., \& Barrainkua, I. (2016). An exploratory study of the pressures and ethical dilemmas in the audit conflict. Revista de Contabilidad, 19(1), 10-20. 
Eynon, G., Hills, N. T., \& Stevens, K. T. (1997). Factors that influence the moral reasoning abilities of accountants: Implications for universities and the profession. Journal of Business ethics, 16(12-13), 1297-1309.

Finn, D. W., \& Lampe, J. C. (1992). A study of whistleblowing among auditors. Professional Ethics, A Multidisciplinary Journal, 1(3/4), 137-168.

Finn, D. W., Chonko, L. B., \& Hunt, S. D. (1988). Ethical problems in public accounting: The view from the top. Journal of Business Ethics, 7(8), 605-615.

Fleming, D. M., Lightner, S. M., \& Romanus, R. N. (2009). The effect of professional context on accounting students' moral reasoning. Issues in Accounting Education, 24(1), 1330.

Fleming, D. M., Chow, C. W., \& Su, W. (2010). An exploratory study of Chinese accounting students' and auditors' audit-specific ethical reasoning. Journal of Business Ethics, 94(3), 353-369.

Flory, S. M., Phillips, T. J., Reidenbach, R. E., \& Robin, D. P. (1993). A Reply to" A Comment on'A Multidimensional Analysis of Selected Ethical Issues in Accounting"'. The Accounting Review, 68(2), 417-421.

Ford, R. C., \& Richardson, W. D. (1994). Ethical decision making: A review of the empirical literature. Journal of business ethics, 13(3), 205-221.

Francis, J. R., \& Yu, M. D. (2009). Big 4 office size and audit quality. The Accounting Review, 84(5), 1521-1552.

Ge, L., \& Thomas, S. (2008). A cross-cultural comparison of the deliberative reasoning of Canadian and Chinese accounting students. Journal of Business Ethics, 82(1), 189211.

Gerged, A. M., Cowton, C. J., \& Beddewela, E. S. (2018). Towards Sustainable Development in the Arab Middle East and North Africa Region: A Longitudinal Analysis of Environmental Disclosure in Corporate Annual Reports. Business Strategy and the Environment, 27(4), 572-587.

Gray, S.J. (1988). Towards a theory of cultural influence on the development of accounting systems internationally. Abacus. Vol. 24: 1-15.

Gul, F. A., \& Tsui, J. (1993). A comparative study of auditors' attitudes to uncertainty qualifications: An empirical test of the strong versus weak uncertainty avoidance hypothesis. International Journal of Accounting, 28(4), 356-364.

Haron, H., Ismail, I., \& Na, A. L. (2015). The effect of moral reasoning, exposure to ethics and perceived ethical climate on ethical judgement of auditors in Malaysia. Asian Journal of Business and Accounting, 8(2), 25-66.

Hegazy, M. A.\& Kamer, N. (2010). A critical analysis of auditors' perception of the impact of Section 404 of the Sarbanes Oxley Act on audit quality: an Egyptian perspective, AfroAsian J. Finance and Accounting, 2(2),154-182.

Hofstede, G. (1984). The cultural relativity of the quality of life concept. Academy of Management review, 9(3), 389-398.

International Ethics Standards Board for Accountants. (2016). Handbook of the code of ethics for professional accountants. New York: International Federation of Accountants (IFAC).

Jensen, M. C., \& Meckling, W. H. (1976). Theory of the firm: Managerial behavior, agency costs and ownership structure. Journal of financial economics, 3(4), 305-360. 
Jeffrey, C., Weatherholt, N., \& Lo, S. (1996). Ethical development, professional commitment and rule observance attitudes: A study of auditors in Taiwan. The international journal of accounting, 31(3), 365-379.

Jones, J.C., Massey, D.W., and Thorne, L. (2003). Auditors ethical reasoning: Insights from past and implications for the future researches. Journal of Accounting Literature, 22:45-103.

Jones, S. K., \& Hiltebeitel, K. M. (1995). Organizational influence in a model of the moral decision process of accountants. Journal of Business Ethics, 14(6), 417-431.

Jones, T.M. (1991). Ethical decision making by individuals in organizations: An issuecontingent model. Academy of Management Review, 16(2):366-395.

Karacaer, S., Gohar, R., Aygün, M., \& Sayin, C. (2009). Effects of personal values on auditor's ethical decisions: A comparison of Pakistani and Turkish professional auditors. Journal of Business Ethics, 88(1), 53-64.

Karaibrahimoglu, Y. Z., \& Cangarli, B. G. (2016). Do auditing and reporting standards affect firms' ethical behaviours? The moderating role of national culture. Journal of Business Ethics, 139(1), 55-75.

Kassem, R. (2018). Exploring external auditors' perceptions of the motivations behind management fraud in Egypt-a mixed methods approach. Managerial Auditing Journal, 33(1), 16-34.

Khlif, H., \& Samaha, K. (2014). Internal Control Quality, Egyptian Standards on Auditing and External Audit Delays: Evidence from the Egyptian Stock Exchange. International Journal of Auditing, 18(2), 139-154.

Khurana, I. K., \& Raman, K. K. (2004). Litigation risk and the financial reporting credibility of Big 4 versus non-Big 4 audits: Evidence from Anglo-American countries. The Accounting Review, 79(2), 473-495.

Kish-Gephart, J. J., Harrison, D. A., \& Trevin o, L. K. (2010). Bad apples, bad cases, and bad barrels: Meta-analytic evidence about sources of unethical decisions at work. Journal of Applied Psychology, 95(1), 1-31.

Kohlberg, L. (1969). Stages in the development of moral thought and action. New York: Holt, Rinehart and Winston.

Kohlberg, L. (1976). Moral stages and moralization: The cognitive developmental. In T. Lickona (Ed.), Moral development and behavior: Theory, research, and social issues. New York: Holt, Rinehart and Winston.

Kohlberg, L. (1981). The philosophy of moral development: Moral stages and the idea of justice (essays on moral development, volume 1). San Fancisco: Harper \& Row.

KPMG (2010). The auditing profession in Egypt, Retrieved from http://www. kpmg.com/EG/en/IssuesAndInsights/Documents/IssuesInsights\%20PDFs/Auditing\% 20 Profession\%20in\%20Egypt-Final.pdf

Iqbal, S., \& Sholihin, M. (2019). The role of cognitive moral development in tax compliance decision making: An analysis of the synergistic and antagonistic tax climates. International Journal of Ethics and Systems. doi:10.1108/IJOES-10-2018-0152

Leung, P. and Cooper, B.J. (1995). Ethical dilemmas in accountancy practice. Australian Accountant, 65, pp.28-28.

Liu, G., \& Ren, H. (2017). Ethical team leadership and trainee auditors' likelihood of reporting client's irregularities. Journal of Financial Crime, 24(1), 157-175.

Liu, M. (2013). Effect of Guanxi and ethical orientations on Chinese auditors' ethical reasoning. Managerial Auditing Journal, 28(9), 815-837. 
Marta, J., Heiss, C. M., \& De Lurgio, S. A. (2008). An exploratory comparison of ethical perceptions of Mexican and US marketers. Journal of Business Ethics, 82(3), 539-555.

McKinnon, J.I.L.L. (1984). Cultural constraints on audit independence in Japan. The International Journal of Accounting, 20(1), 17-44.

Moardi, M., Marandi, Z., \& Salehi, M. (2016). The role of tolerance of ambiguity on ethical decision-making students: A comparative study between accounting and management students. Humanomics, 32(3), 300-327.

Morris, J, (2014). The impact of authentic leadership and ethical firm culture on auditor behavior. Journal of Behavioral Studies in Business, 7(1):1-32.

Mostafa, D., Ehab, K. A., \& Hussain, M. M. (2017). The Effect of Religiosity \& Morality Interaction on the Degree of Auditor Independence: The Case of Egypt. https://ssrn.com/abstract=2899354 or http://dx.doi.org/10.2139/ssrn.2899354

Mostafa, W. (2017). The impact of earnings management on the value relevance of earnings: Empirical evidence from Egypt. Managerial Auditing Journal, 32(1), 50-74.

Musbah, A., Cowton, C.J., and Tyfa, D. (2016). The role of individual variables, organizational variables and moral intensity dimensions in Libyan management accountants' ethical decision making. Journal of Business Ethics, 134(3):335-358.

Naslmosavi, S., Sofian, S. and Saat, M.B.M. (2013). The effect of audit firm size on independent auditor's opinion: Conceptual framework, Asian Social Science, 9 (9):243-248.

Palmrose, Z. V. (1988). 1987 Competitive Manuscript Co-Winner: An analysis of auditor litigation and audit service quality. Accounting review, 55-73.

Peterson, J. (2017). Count Down: The Past, Present and Uncertain Future of the Big Four Accounting Firms. Emerald Publishing Limited.

Phau, I., \& Kea, G. (2007). Attitudes of university students toward business ethics: A crossnational investigation of Australia, Singapore and Hong Kong. Journal of Business Ethics, 72(1), 61-75.

Pierce, B., \& Sweeney, B. (2010). The relationship between demographic variables and ethical decision making of trainee accountants. International journal of auditing, 14(1), 79-99.

Ponemon, L. A. (1992). Ethical reasoning and selection-socialization in accounting. Accounting, Organizations and Society, 17(3-4), 239-258.

Ponemon, L., \& Gabhart, D. (1993). Ethical Reasoning in Accounting and Auditing (Canadian General Accountants' Research Foundation, Vancouver).

Ponemon, L. A., (1988). A cognitive-developmental approach to the analysis of certified public accountants' ethical judgments, Union College- PhD dissertation.

Ponemon, L. A. (1990). Ethical judgments in accounting: A cognitive-developmental perspective. Critical Perspectives on Accounting, 1(2), 191-215.

Ponemon, L.A. and Gabhart, D.R.L. (1990). Auditor independence judgements: A cognitive developmental model and experimental evidence. Contemporary Accounting Research, 7(1):227-51.

Puddephatt, A. (2012). Corruption in Egypt. Global Partners and Associates. https://www.gpdigital.org/wp-content/uploads/pubs/Corruption-in-Egypt-Report-new-cover.pdf.

Rest, J. R. (1986). Manual for the Defining Issues Test. Minneapolis, MN: University of Minnesota. Center for the Study of Ethical Development.

Rest, J. R. (1993). Guide for the defining issues test. Minneapolis: Center for the Study of Ethical Development. 
ROSC (2002). Report on the observance of standards and codes (Egypt, Arab Republic), accounting and auditing, November, pp. 1-18.

Said Mokhtar, E., \& Mellett, H. (2013). Competition, corporate governance, ownership structure and risk reporting. Managerial Auditing Journal, 28(9), 838-865.

Samaha, K., \& Hegazy, M. (2010). An empirical investigation of the use of ISA 520 "analytical procedures" among Big 4 versus non-Big 4 audit firms in Egypt. Managerial Auditing Journal, 25(9), 882-911.

Samaha, K., \& Stapleton, P. (2008). Compliance with International Accounting Standards in a national context: some empirical evidence from the Cairo and Alexandria Stock Exchanges. Afro-Asian Journal of Finance and Accounting, 1(1), 40-66.

Samaha, K., \& Stapleton, P. (2009). Firm-specific determinants of the extent of compliance with international accounting standards in the corporate annual reports of companies listed on the Egyptian Stock Exchange: a positive accounting approach. Afro-Asian Journal of Finance and Accounting, 1(3), 266-294.

Samaha, K., Dahawy, K., Hussainey, K., \& Stapleton, P. (2012). The extent of corporate governance disclosure and its determinants in a developing market: The case of Egypt. Advances in Accounting, 28(1), 168-178.

Sayyadi Tooranloo, H., \& Azizi, P. (2018). An analysis of causal relationships of ethical values in auditing from Islam's perspective: Using fuzzy DEMATEL approach. International Journal of Ethics and Systems, 34(3), 393-422.

Seifert, D. L., Sweeney, J. T., Joireman, J., \& Thornton, J. M. (2010). The influence of organizational justice on accountant whistleblowing. Accounting, Organizations and Society, 35(7), 707-717.

Shaub, M. K. (1989). An empirical examination of the determinants of auditors' ethical sensitivity (Doctoral dissertation, Texas Tech University).

Shaub, M. K. (1994). An analysis of the association of traditional demographic variables with the moral reasoning of auditing students and auditors. Journal of Accounting Education, 12(1), 1-26.

Sorensen, D. P., Miller, S. E., \& Cabe, K. L. (2017). Developing and measuring the impact of an accounting ethics course that is based on the moral philosophy of Adam Smith. Journal of business ethics, 140(1), 175-191.

Spector, M., Glazer, E., \& Smith, R. (2014, 29 April). Energy future holdings files for bankruptcy. The Wall Street Journal

Sun, J., \& Liu, G. (2011). Client-specific litigation risk and audit quality differentiation. Managerial Auditing Journal, 26(4), 300-316.

Sundgren, S., \& Svanström, T. (2013). Audit office size, audit quality and audit pricing: evidence from small-and medium-sized enterprises. Accounting and Business Research, 43(1), 31-55.

Svanberg, J., \& Öhman, P. (2013). Auditors' time pressure: does ethical culture support audit quality?. Managerial Auditing Journal, 28(7), 572-591.

Svanström, T. (2016). Time pressure, training activities and dysfunctional auditor behaviour: evidence from small audit firms. International Journal of Auditing, 20(1), 42-51.

Svanström, T., \& Sundgren, S. (2012). The Demand for Non-Audit Services and Auditor-Client Relationships: Evidence from Swedish Small and Medium-Sized Enterprises. International Journal of Auditing, 16(1), 54-78. 
Sweeney, B., Arnold, D., \& Pierce, B. (2010). The impact of perceived ethical culture of the firm and demographic variables on auditors' ethical evaluation and intention to act decisions. Journal of Business Ethics, 93(4), 531-551.

Sweeney, B., Pierce, B., \& Arnold Sr, D. F. (2013). The impact of perceived ethical intensity on audit-quality-threatening behaviours. Accounting and Business Research, 43(2), 112-137.

Sweeney, J. (1995). The moral expertise of auditors: An exploratory analysis. Research on accounting ethics, 1(2), 213-234

Sweeney, J. T., \& Fisher, D. G. (1998). An examination of the validity of a new measure of moral judgment. Behavioral Research in Accounting, 10, 138.

Tervo, W., Smith, L. M., \& Pitman, M. (2014). Dysfunctional auditor behavior: the effects of tone at the top and supervisors' relationships. In Research on professional responsibility and ethics in accounting (pp. 47-77). Emerald Group Publishing Limited.

Thorne, L. (1999). An analysis of the association of demographic variables with the cognitive moral development of Canadian accounting students: An examination of the applicability of American-based findings to the Canadian context. Journal of Accounting Education, 17(2-3), 157-174.

Thorne, L. (2000). The development of two measures to assess accountants' prescriptive and deliberative moral reasoning. Behavioral Research in Accounting, 12, 139- 169.

Thorne, L., Massey, D. W., \& Magnan, M. (2003). Institutional context and auditors' moral reasoning: A Canada-US comparison. Journal of Business Ethics, 43(4), 305-321.

Trevino, L. K. (1992). Moral reasoning and business ethics: Implications for research, education, and management. Journal of Business Ethics, 11(5-6), 445-459.

Trevino, L. K., \& Brown, M. E. (2004). Managing to be ethical: Debunking five business ethics myths. Academy of management perspectives, 18(2), 69-81.

Tsui, J., \& Windsor, C. (2001). Some cross-cultural evidence on ethical reasoning. Journal of Business Ethics, 31(2), 143-150.

Tsui, J. S. (1996). Auditors' ethical reasoning: Some audit conflict and cross cultural evidence. The International Journal of Accounting, 31(1), 121-133.

Vitell, S. J., \& Festervand, T. A. (1987). Business ethics: Conflicts, practices and beliefs of industrial executives. Journal of Business Ethics, 6(2), 111-122.

Weber, J. (2017). Understanding the Millennials' Integrated Ethical Decision-Making Process: Assessing the Relationship Between Personal Values and Cognitive Moral Reasoning. Business \& Society, 0007650317726985.

Wilhelm, W. J., \& Gunawong, P. (2016). Cultural dimensions and moral reasoning: a comparative study. International Journal of Sociology and Social Policy, 36(5/6), 335357.

Windsor, C. A., \& Ashkanasy, N. M. (1995). The effect of client management bargaining power, moral reasoning development, and belief in a just world on auditor independence. Accounting, Organizations and Society, 20(7-8), 701-720.

Yuniarti, R. (2011).Audit firm size, audit fee and audit quality. https://repository.widyatama.ac.id/xmlui/bitstream/handle/123456789/2414/CONT ENTS\%20RITA.pdf?sequence $=5$

Uyar, A., \& GÜNGÖRMÜŞ, A. H. (2013). Accounting professionals' perceptions of ethics education: evidence from Turkey. Accounting and Management Information Systems, 12(1), 61-75. 
Zerban, A. M. (2017). Enron of Saudi Arabia: Corporate Accounting and Auditing Failures. Open Journal of Accounting, 7(01), 1-18.

Zureigat, Q. M. (2015). Factors associated with audit reports in Saudi Arabia. Global Journal of Management and Business Research, 14(5), 67-74. 
Tables

Table 1. Kohlberg's six stages of moral development

\begin{tabular}{l|l}
\hline Level & Stage \\
\hline Pre-conventional level & Stage 1: Punishment and obedience \\
& Stage 2: Individualism and rewards (hedonistic) \\
\hline Conventional level & Stage 3: Approval of group (good boy/girl) \\
& Stage 4: Orientation to authority (law and order) \\
\hline Post-conventional level & Stage 5: Social contract orientation \\
& Stage 6: Principled conscience \\
\hline
\end{tabular}

Sources: Adapted from Kohlberg (1969). 
Table 2: Summary of the sample procedures

\begin{tabular}{|c|c|c|c|c|c|c|c|c|c|c|}
\hline \multirow{3}{*}{ Sample } & \multicolumn{8}{|c|}{ Categories of auditors / firms } & \multirow{2}{*}{\multicolumn{2}{|c|}{ Total }} \\
\hline & \multicolumn{4}{|c|}{ Managers } & \multicolumn{4}{|c|}{ Juniors } & & \\
\hline & Big & Med & Small & CAO & Big & Med & Small & CAO & Number & $\%$ \\
\hline $\begin{array}{l}\text { Delivered } \\
\text { Surveys }\end{array}$ & 15 & 10 & 9 & 13 & 85 & 35 & 16 & 49 & 232 & 100 \\
\hline $\begin{array}{l}\text { Returned } \\
\text { Surveys }\end{array}$ & 11 & 10 & 7 & 13 & 52 & 30 & 14 & 47 & 184 & 79.3 \\
\hline $\begin{array}{l}\text { Analyzed } \\
\text { Surveys }\end{array}$ & 10 & 10 & 7 & 13 & 49 & 30 & 12 & 47 & 178 & 76.7 \\
\hline $\begin{array}{l}\text { Reliable } \\
\text { surveys }\end{array}$ & 10 & 10 & 7 & 13 & 49 & 30 & 12 & 47 & 178 & 76.7 \\
\hline
\end{tabular}


Table 3. Reliability analysis

\begin{tabular}{lllll}
\hline Surveys number & Alpha value & Assessment & Reliability & Assessment \\
\hline 178 & 0.82 & High & 0.91 & High \\
\hline
\end{tabular}


Table 4. Mean value of ethical reasoning of Egyptian auditors

\begin{tabular}{llllll}
\hline Sample & Firms & N & Mean \% & SD & Ethical level \\
\hline All items & All items & 178 & 44.9 & 14.9 & Post - conventional level \\
\hline
\end{tabular}


Table 5. Mean value of the $\boldsymbol{P}$-score results to auditors in different sized firms and in CAO

\begin{tabular}{llllll}
\hline Sample & Firms & $\mathbf{N}$ & Mean \% & SD & Ethical level \\
\hline Big firms & 2 & 59 & 38.6 & 13.2 & Conventional \\
\hline Medium firms & 2 & 40 & 39,8 & 11.9 & Conventional \\
\hline Small firms & 3 & 19 & 47.8 & 6.6 & Post-conventional \\
\hline CAO & & 60 & 53.3 & 16.6 & Post-conventional \\
\hline
\end{tabular}


Table 6: Regression analysis of the determinants of ethical reasoning in Egypt

\begin{tabular}{|l|l|l|l|l|}
\hline \multirow{2}{*}{ Variables } & \multicolumn{2}{|c|}{ (1) Full sample } & \multicolumn{2}{l|}{ (2) Full sample without CAO obs } \\
\cline { 2 - 5 } \multicolumn{2}{|l|}{ Coefficients } & P-value & Coefficients & P-value \\
\hline Independent variables & & \\
\hline Audit firm size & $-2.2588^{* * *}$ & 0.000 & $-1.0828 * * *$ & 0.003 \\
\hline Auditor position & $-1.4895^{* * *}$ & 0.003 & $-2.6437 * * *$ & 0.000 \\
\hline Control variables \\
\hline Education level & -0.6230 & 0.781 & -0.0530 & 0.368 \\
\hline Age & -0.1507 & 0.493 & -0.0189 & 0.916 \\
\hline Audit experience & $1.1174 * * *$ & 0.000 & -0.4438 & 0.441 \\
\hline Gender & $-0.2587 * *$ & 0.013 & $1.7991 * * *$ & 0.000 \\
\hline chi2 & $28.58 * * *$ & & $32.28 * * *$ & \\
\hline Pseudo R2 & 0.1008 & 0.1530 & \\
\hline Number of obs & 178 & 118 & \\
\hline
\end{tabular}

Notation: T-statistics are in parenthesis. *, **, and *** indicate significance at the $10 \%, 5 \%$, and $1 \%$ levels, respectively. Coefficients are in front of parenthesis. 
Table 7. Mean value of the P-score results to auditors in different sized firms and in CAO (Managers - juniors)

\begin{tabular}{|c|c|c|c|c|c|}
\hline Category & Firms & $\mathrm{N}$ & Mean & SD & Ethical level \\
\hline \multirow{4}{*}{ Managers } & Big & 10 & 26.28 & 10.58 & Pre-conventional \\
\hline & Medium & 10 & 32.96 & 14.18 & Conventional \\
\hline & Small & 7 & 44.73 & 14.08 & Post -conventional \\
\hline & $\mathrm{CAO}$ & 13 & 57.92 & 14.05 & Post -conventional \\
\hline \multirow{4}{*}{ Juniors } & Big & 49 & 41.67 & 12.19 & Conventional \\
\hline & Medium & 30 & 42.19 & 10.44 & Post -conventional \\
\hline & Small & 12 & 49.69 & 6.88 & Post -conventional \\
\hline & $\mathrm{CAO}$ & 47 & 52.03 & 16.63 & Post -conventional \\
\hline
\end{tabular}


Table 8. $T$ test of the audit managers and the juniors

\begin{tabular}{lllllll}
\hline Firms & Category & $\mathrm{N}$ & Mean & SD & T & Sig \\
\hline \multirow{2}{*}{ Big } & Managers & 10 & 26.28 & 10.58 & $3.709 * * *$ & 0.001 \\
\cline { 2 - 5 } Med & Juniors & 49 & 41.67 & 12.19 & & \\
\cline { 2 - 5 } & Managers & 7 & 31.85 & 13.026 & $2.024 * *$ & 0.050 \\
\cline { 2 - 5 } & Juniors & 33 & 41.58 & 11.249 & & \\
\hline \multirow{2}{*}{ Small } & Managers & 7 & 44.73 & 5.408 & 1.629 & 0.122 \\
\cline { 2 - 5 } & Juniors & 12 & 49.69 & 6.889 & & \\
\hline \multirow{2}{*}{ CAO } & Managers & 13 & 57.92 & 14.048 & \multirow{2}{*}{1.166} & 0.248 \\
\cline { 2 - 5 } & Juniors & 47 & 52.03 & 16.63 & & \\
\hline
\end{tabular}




\section{Figures}

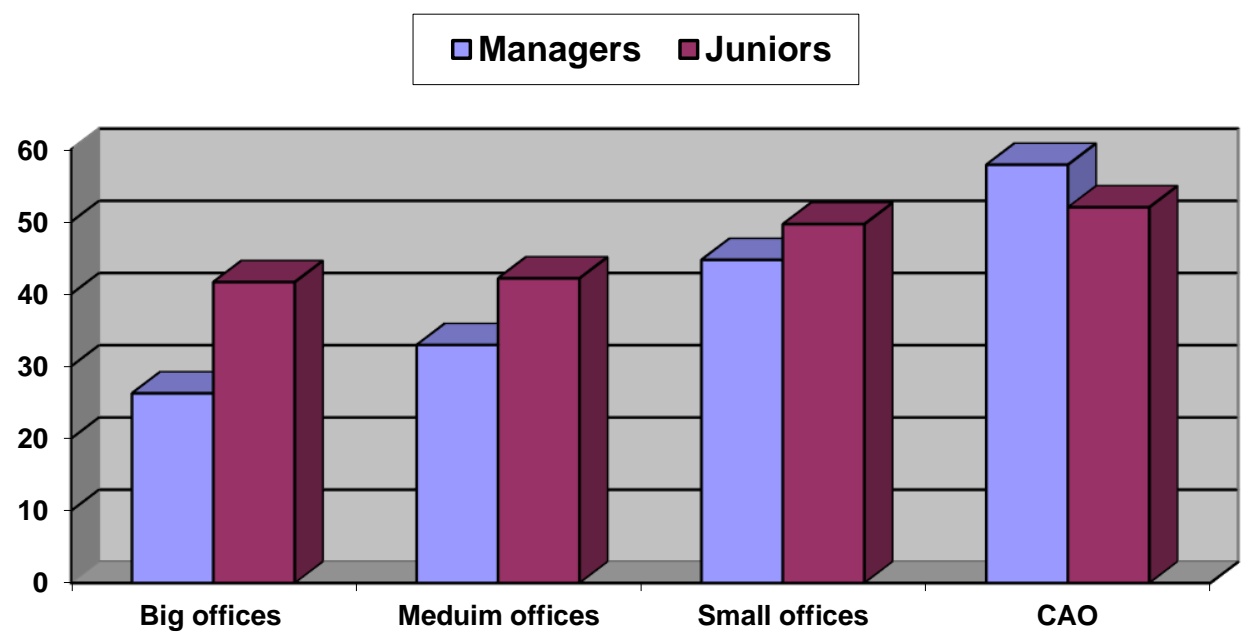

Fig 1. Levels of ethical reasoning of the audit managers and the juniors in different firms and $\mathrm{CAO}$ 